\title{
APLIKASI TIME SERIES ANALYSIS UNTUK KARAKTERISASI AKUIFER KARST
}

\author{
${ }^{1}$ Afid Nurkholis, ${ }^{2}$ Tjahyo Nugroho Adji, ${ }^{3}$ Ahmad Cahyadi \\ ${ }^{1,2,3}$ Karst Research Group, Fakultas Geografi, Universitas Gadjah Mada \\ Email author: afidnurkholis@ gmail.com
}

\begin{abstract}
Abstrak
Time series analysis merupakan suatu analisis statistik yang mencerminkan respons sistem karst terhadap curah hujan. Konsep dari metode ini adalah menganggap sistem akuifer karst sebagai black box yang tidak diketahui kinerjanya. Time series analysis menggunakan perhitungan statistik berupa univariate (autocorrelation) dan bivariate (cross-correlation). Kedua metode menganalisis data berdasarkan waktu dan dapat diubah bentuk menjadi analisis frekuensi. Autocorrellation dapat diubah menjadi spectral density. Cross-correlation dapat diubah menjadi cross-amplitude, phase function, coherency function, dan gain function. Tulisan ini akan menjelaskan langkah-langkah perhitungan seluruh metode time series analysis tersebut untuk melakukan karakterisasi akuifer karst. Data yang digunakan adalah pasangan debit aliran dan curah hujan selama 6 bulan (1 Januari 2017 - 30 Juni 2017). Kedua data dicatat pada Gua Pindul (sebagai outlet sistem akuifer karst) dan Sinking Stream Kedungbuntung. Hasil perhitungan menunjukkan bahwa time series analysis dapat diklasifikan menjadi pelepasan aliran conduit, fissure, dan diffuse.
\end{abstract}

Kata kunci: time series analysis, auto-correlation, cross-correlation, akuifer karst, karakterisasi akuifer, Gua Pindul

\section{Sitasi model APA}

Nurkholis, A., \& Adji, T. N. (2018, April 10). APLIKASI TIME SERIES ANALYSIS UNTUK KARAKTERISASI AKUIFER KARST. http://doi.org/10.17605/OSF.IO/HZ54T 


\section{APLIKASI TIME SERIES ANALYSIS UNTUK KARAKTERISASI AKUIFER KARST}

\section{Pendahuluan}

Time series analysis merupakan suatu analisis statistik yang mencerminkan respons sistem karst terhadap curah hujan. Konsep dari metode ini adalah menganggap sistem akuifer karst sebagai black box yang tidak diketahui kinerjanya (Ford \& Williams, 1989). Analisis dilakukan melalui hubungan input (curah hujan) dengan output (debit aliran atau muka airtanah) yang diolah secara statistik (Mangin, 1984; Kovacs dan Sauter, 2007) (Gambar 1).

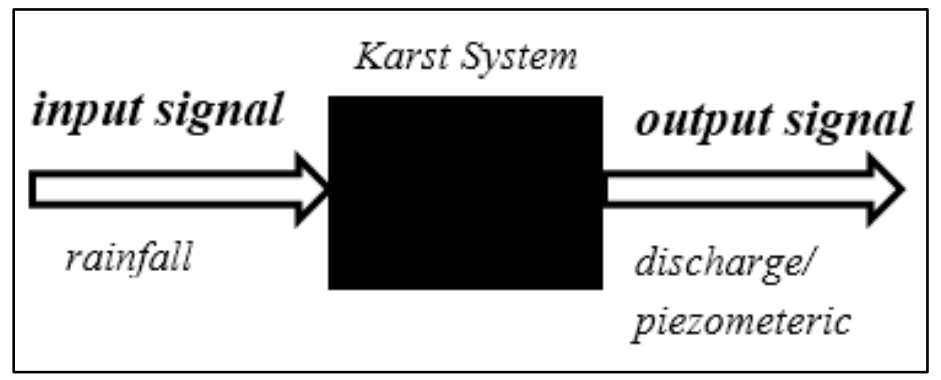

Gambar 1. Ilustrasi time series analysis sebagai model black box

Time series analysis menggunakan perhitungan statistik berupa univariate (auto-correlation) dan bivariate (cross-correlation) (Kovacs dan Sauter, 2007). Kedua metode menganalisis data berdasarkan waktu dan dapat diubah bentuk menjadi analisis frekuensi. Auto-correllation dapat diubah menjadi spectral density. Cross-correlation dapat diubah menjadi cross-amplitude, phase function, coherency function, dan gain function. Zang dkk, (2013) mengklasifikasikan metode time series analysis untuk karakterisasi sistem akuifer karst (Tabel 1). Panagopoulus dan Lambarakis (2006) menjelaskan metode-metode tersebut dalam kaitannya dengan karakterisasi sistem akuifer karst, yaitu:

\subsection{Auto-Correlation}

Auto-correlation juga disebut sebagai univariate karena hanya menggunakam satu signal (debit aliran atau TMA). Persamaan metode ini adalah sebagai berikut: 
Tabel 1. Klasifikasi time series analysis untuk karakterisasi sistem akuifer karst (Zang dkk, 2013)

\begin{tabular}{|c|c|c|c|c|}
\hline \multicolumn{2}{|c|}{$\begin{array}{c}\text { Respons Sistem } \\
\text { Akuifer Karst }\end{array}$} & Definisi & Metode & Indikator \\
\hline \multirow{4}{*}{$\begin{array}{l}\text { Aliran } \\
\text { Conduit }\end{array}$} & \multirow{3}{*}{$\begin{array}{l}\text { Waktu Tunda } \\
\text { Aliran } \\
\text { Conduit }\end{array}$} & \multirow{3}{*}{$\begin{array}{l}\text { Nilai rerata } \\
\text { respons cepat } \\
\text { hidrograf terhadap } \\
\text { hujan. Tlag } \\
\text { dihitung pada } \\
\text { rising limb } \\
\text { hidrograf }\end{array}$} & $\begin{array}{c}\text { Cross- } \\
\text { Correlation }\end{array}$ & $\begin{array}{c}\text { waktu dari puncak } \\
\text { grafik }\end{array}$ \\
\hline & & & $\begin{array}{c}\text { Phase } \\
\text { Functions }\end{array}$ & $\begin{array}{c}\text { time } \operatorname{delay}(\mathrm{d})= \\
\theta \mathrm{xy}(\mathrm{f})) / 2 \pi \mathrm{f}\end{array}$ \\
\hline & & & $\begin{array}{l}\text { Cross- } \\
\text { Amplitude }\end{array}$ & $\begin{array}{c}\text { nilai ketika } \\
\text { mendekati enol }\end{array}$ \\
\hline & $\begin{array}{l}\text { Durasi } \\
\text { Minimum } \\
\text { Aliran } \\
\text { Conduit }\end{array}$ & $\begin{array}{l}\text { Durasi minimum } \\
\text { pelepasan aliran } \\
\text { conduit yang } \\
\text { dihitung dari } \\
\text { resesi Kc }\end{array}$ & $\begin{array}{c}\text { Gain } \\
\text { Functions }\end{array}$ & $\operatorname{gxy}(f)<0,4$ \\
\hline \multirow{3}{*}{$\begin{array}{l}\text { Aliran } \\
\text { Diffuse }\end{array}$} & \multirow{2}{*}{$\begin{array}{c}\text { Rerata } \\
\text { Durasi Aliran } \\
\text { Diffuse }\end{array}$} & \multirow{2}{*}{$\begin{array}{l}\text { Rerata durasi yang } \\
\text { dihitung } \\
\text { menggunakan } \mathrm{Kb}\end{array}$} & $\begin{array}{c}\text { Auto- } \\
\text { Correlation }\end{array}$ & $\begin{array}{c}\text { memory effect }(C)= \\
2 /\left(\mathrm{n}^{\wedge} 0,5\right)\end{array}$ \\
\hline & & & $\begin{array}{c}\text { Spectral } \\
\text { Density } \\
\text { Functions }\end{array}$ & $\begin{array}{c}\text { regulation } \\
\text { time }(\text { Treg })= \\
\mathrm{S}(\mathrm{f}=0) / 2\end{array}$ \\
\hline & $\begin{array}{c}\text { Durasi } \\
\text { Maksimum } \\
\text { Aliran } \\
\text { Diffuse }\end{array}$ & $\begin{array}{l}\text { Durasi maksimum } \\
\text { pelepasan aliran } \\
\text { diffuse yang } \\
\text { dihitung dari } \\
\text { resesi } \mathrm{Kb} \\
\end{array}$ & $\begin{array}{c}\text { Gain } \\
\text { Functions }\end{array}$ & $\operatorname{gxy}(f)>1$ \\
\hline \multirow{3}{*}{$\begin{array}{l}\text { Aliran } \\
\text { Fissure }\end{array}$} & \multirow{2}{*}{$\begin{array}{l}\text { Rerata } \\
\text { Durasi Aliran } \\
\text { Fissure }\end{array}$} & \multirow{2}{*}{$\begin{array}{l}\text { Rerata durasi yang } \\
\text { dihitung } \\
\text { menggunakan Ki }\end{array}$} & $\begin{array}{c}\text { Auto- } \\
\text { Correlation }\end{array}$ & $\begin{array}{c}\text { permulaan } \\
\text { penurunan tajam } \\
\text { grafik }\end{array}$ \\
\hline & & & $\begin{array}{c}\text { Cross- } \\
\text { Correlation }\end{array}$ & $\begin{array}{c}\text { permulaan } \\
\text { penurunan tajam } \\
\text { grafik }\end{array}$ \\
\hline & $\begin{array}{l}\text { Durasi Aliran } \\
\text { Fissure }\end{array}$ & $\begin{array}{c}\text { Durasi yang } \\
\text { dihitung pada } \\
\text { selang antara Kc } \\
\text { dengan } \mathrm{Kb}\end{array}$ & $\begin{array}{c}\text { Gain } \\
\text { Functions }\end{array}$ & $0,4<\operatorname{gxy}(f)<1$ \\
\hline
\end{tabular}

$$
r(k)=\frac{C(k)}{C(0)}
$$




$$
\begin{aligned}
& C(k)=\frac{1}{n} \sum_{t=1}^{n-k}\left(x_{t}-\bar{x}\right)\left(x_{t+k}-\bar{x}\right) . \\
& C(0)=\frac{1}{n} \sum_{t=1}^{n}\left(x_{t}-\bar{x}\right)^{2} \ldots \ldots \ldots \ldots \ldots \ldots \ldots \ldots
\end{aligned}
$$

$\mathrm{C}(\mathrm{k})$ adalah correlogram yang menunjukkan memory effect, yaitu kemampuan sistem dalam menyimpan input signal (curah hujan). Karst yang telah berkembang akan menyimpan input signal dalam waktu yang lebih lama dibandingkan karst yang belum berkembang. Bentuk correlogram diidentikkan dengan grafik resesi hidrograf banjir. Oleh karena itu, grafik $\mathrm{C}(\mathrm{k})$ pada predetermined value menunjukkan durasi pelepasan komponen baseflow/diffuse (durasi penyimpanan input signal) (Gambar 2). Nilai predetermined value dihitung menggunakan persamaan 4.

$$
C(k)=\frac{2}{\sqrt{\text { banyak data }}}
$$

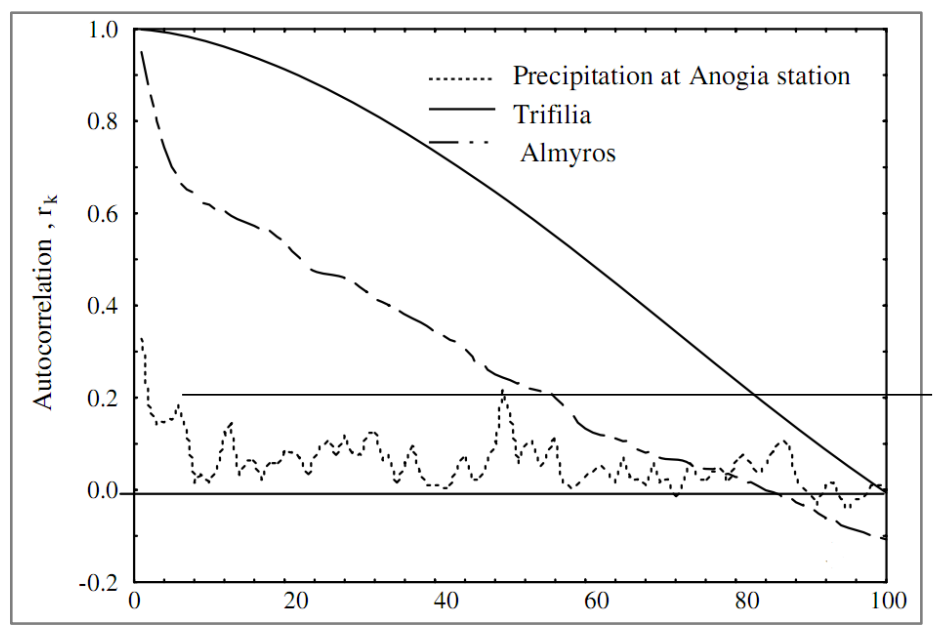

Gambar 2. Contoh auto-correlation di dua sistem karst berbeda, Trifilia (dominasi baseflow) dan Almyros (dominasi quickflow) (Panagopoulus dan Lambarakis, 2006)

\subsection{Spectral Density}

Hubungan auto-correlation dapat diubah menjadi frekuensi yang menghasilkan nilai spectral density. Persamaan spectral density adalah sebagai berikut:

$$
\begin{aligned}
& S(f)=2\left[1+2 \sum_{k=1}^{m} D(k) r(k) \cos (2 \pi f k)\right] \\
& D(k)=\frac{1+\cos \pi \frac{k}{m}}{2} \ldots \ldots \ldots \ldots \ldots \ldots \ldots \ldots \ldots \ldots \ldots \ldots \ldots \ldots \ldots \ldots \ldots \ldots \ldots \ldots \ldots \ldots \ldots \ldots \ldots \ldots \ldots \ldots
\end{aligned}
$$


Spectral density menunjukkan distribusi data pada berbagai frekuensi, dimana puncakpuncak grafik meggambarkan siklus atau pola banjir dari suatu sistem karst (Gambar 3). Larocque dkk (2013) dan Zang dkk (2013) menerangkan bahwa $\mathrm{T}_{\text {reg }}$ (time regulation) merupakan durasi penyimpanan input signal oleh sistem yang dapat diukur melalui grafik spectral density. Konsep ini menyerupai memory effect pada auto-correlation. Persamaan $\mathrm{T}_{\text {reg }}$ adalah sebagai berikut:

$$
\text { Treg }=\frac{S(f=0)}{2}
$$

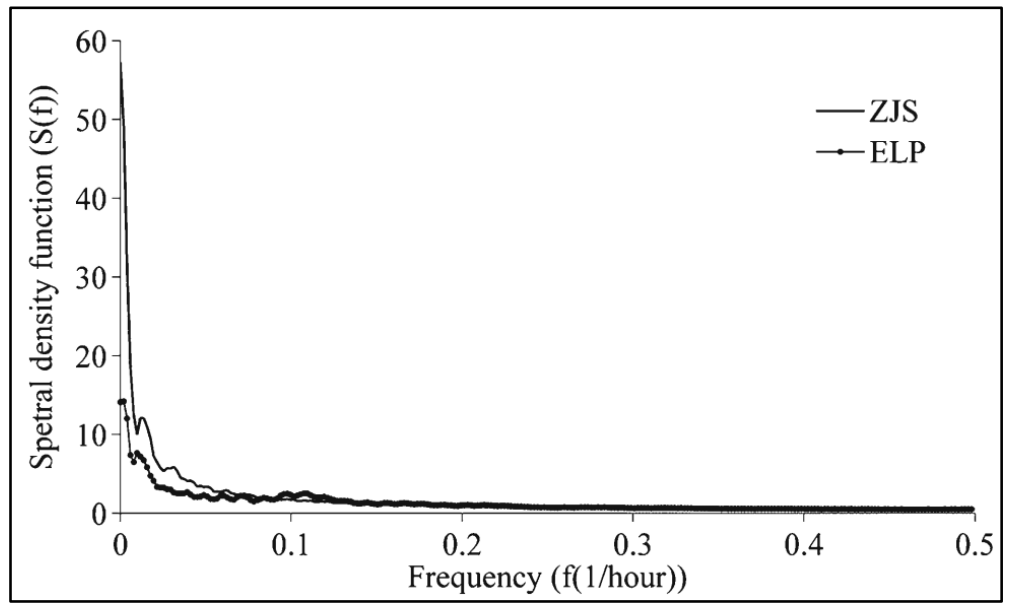

Gambar 3. Contoh gafik spectral density, ZJS melepaskan aliran diffuse lebih lambat dibandingkan ELP (Zang, dkk, 2013)

\subsection{Cross-Correlation}

Cross-correlation merupakan hubungan antata input signal (curah hujan) dengan output signal (debit aliran) sehingga disebut juga hubungan bivariate (Gambar 4). Persamaan dari hubungan ini adalah sebagai berikut:

$$
\begin{aligned}
& r_{x y}(k)=\frac{C_{x y}(k)}{\sqrt{C_{x(0)}^{2} C_{y(0)}^{2}}} . \\
& C_{x y}(k)=\frac{1}{n} \sum_{t=1}^{n-k}\left(x_{t}-\bar{x}\right)\left(y_{t+k}-\bar{y}\right) \\
& C_{x}(0)=\frac{1}{n} \sum_{t=1}^{n}\left(x_{t}-\bar{x}\right)^{2} \\
& C_{y}(0)=\frac{1}{n} \sum_{t=1}^{n}\left(y_{t}-\bar{y}\right)^{2}
\end{aligned}
$$




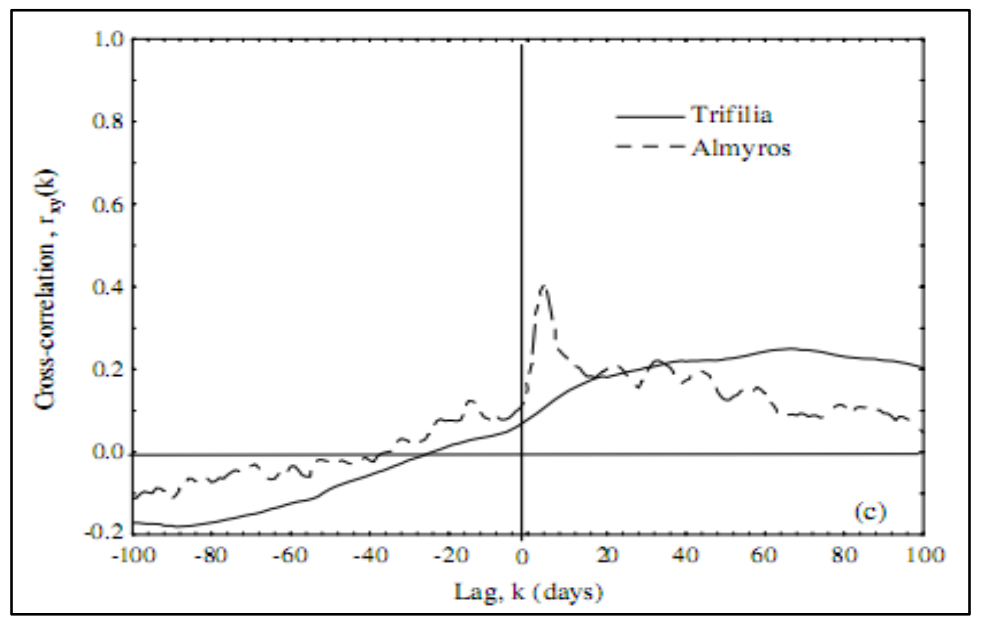

Gambar 4. Contoh cross-correlogram, Almyron merupakan karst yang berkembang sehingga memiliki Tlag yang lebih cepat dibandingkan Trifilias (Panagopoulus dan Lambarakis, 2006)

$\mathrm{C}_{\mathrm{xy}}(\mathrm{k})$ merupakan cross-correlogram, dimana nilai $\mathrm{T}_{\mathrm{lag}}$ (waktu tunda) adalah rentang antara nilai $\mathrm{T}_{\text {lag }}\left(\right.$ sumbu $\mathrm{x}$ ) ketika nol hingga puncak cross-correlogram. Nilai $\mathrm{C}_{\mathrm{xy}}(\mathrm{k})$ menunjukkan seberapa cepat hujan akan muncul sebagai debit aliran di titik pengukuran. Oleh karena itu, cross-correlgram diidentikkan dengan hidrograf banjir yang memiliki rising limb, debit puncak, dan resesi. Tlag pada metode ini menggambarkan respons sistem karst terhadap aliran conduit. Karst yang telah berkembang akan mempunyai Tlag yang cepat (Gambar 4).

\subsection{Cross-Amplitude}

Nilai cross-correlation yang diubah dari satuan waktu menjadi frekuensi akan menghasilkan cross-amplitude. Persamaan cross-amplitude ini adalah sebagai berikut:

$$
\begin{aligned}
& S_{x y}(f)=h_{x y}(f)-i \lambda_{x y}(f) \\
& h_{x y}(f)=2\left\{r_{x y}(0)+\sum_{1}^{m}\left[r_{x y}(k)+r_{y x}(k)\right] D(k) \cos (2 \pi f k)\right\} \\
& \lambda_{x y}(f)=2\left\{\sum_{1}^{m}\left[r_{x y}(k)-r_{y x}(k)\right] D(k) \sin (2 \pi f k)\right\}
\end{aligned}
$$

$\mathrm{S}_{\mathrm{xy}}$ merupakan cross-amplitude yang menunjukkan seberapa lama input signal (hujan) difilter oleh sistem karst sebelum keluar sebagai output signal (debit aliran). Menurut Zang, dkk (2013), nilai tersebut menunjukkan $\mathrm{T}_{\text {lag }}$ maksimum sistem akuifer karst 
dalam merespons aliran conduit. Nilai tersebut terjadi ketika $S_{x y}$ mendekati nol. Karst yang telah berkembang akan mempunyai Tlag maksimum lebih cepat (Gambar 5).

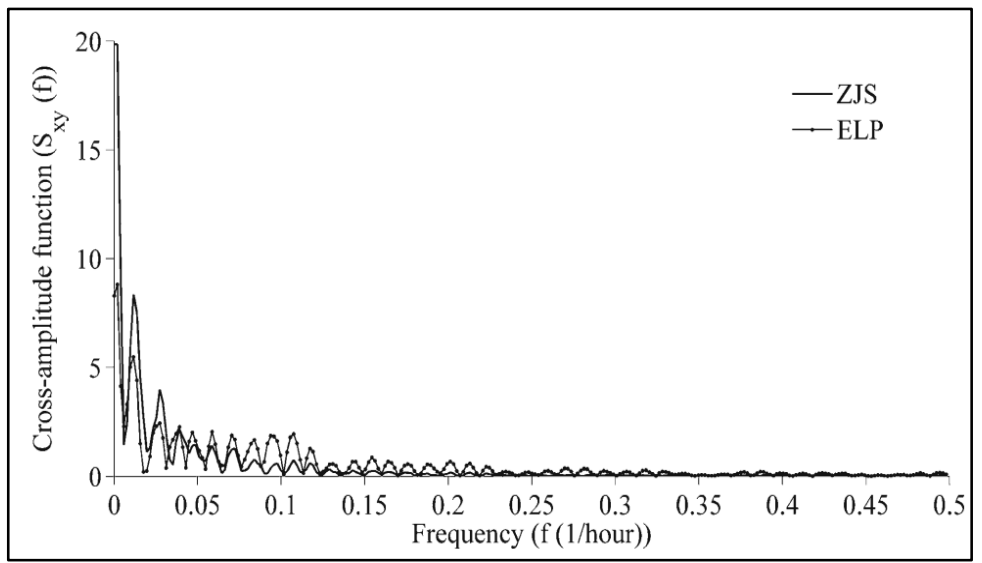

Gambar 5. Contoh grafik cross-amplitude, ELP merupakan karst berkembang yang memiliki nilai Sxy lebih cepat mendekati enol daripada ZJS

(Zang, dkk, 2013).

\subsection{Phase Functions}

Phase function merupakan hasil modifikasi dari cross-amplitude, persamaan tersebut adalah sebagai berikut:

$$
\theta_{x y}(f)=\arctan \frac{\lambda_{x y}(f)}{h_{x y}(f)}
$$

Nilai $\theta_{\mathrm{xy}}$ merupakan phase yang menunjukkan perbedaan frekuensi antara input signal dengan output signal. Perbedaan frekuensi ini terjadi karena adanya input signal (hujan) yang difilter oleh sistem karst. Nilai tersebut memiliki kegunaan yang sama dengan cross-correlation, yaitu menunjukkan $\mathrm{T}_{\text {lag }}$ atau waktu jeda terhadap aliran conduit. Waktu jeda (d) dari phase functions dihitung dengan persamaan berikut:

$$
\boldsymbol{d}=\frac{\theta_{x y}(f)}{2 \pi f}
$$

Karst yang berkembang akan mempuyai nilai d yang lebih cepat dibanding karst yang belum berkembang (Gambar 6) 

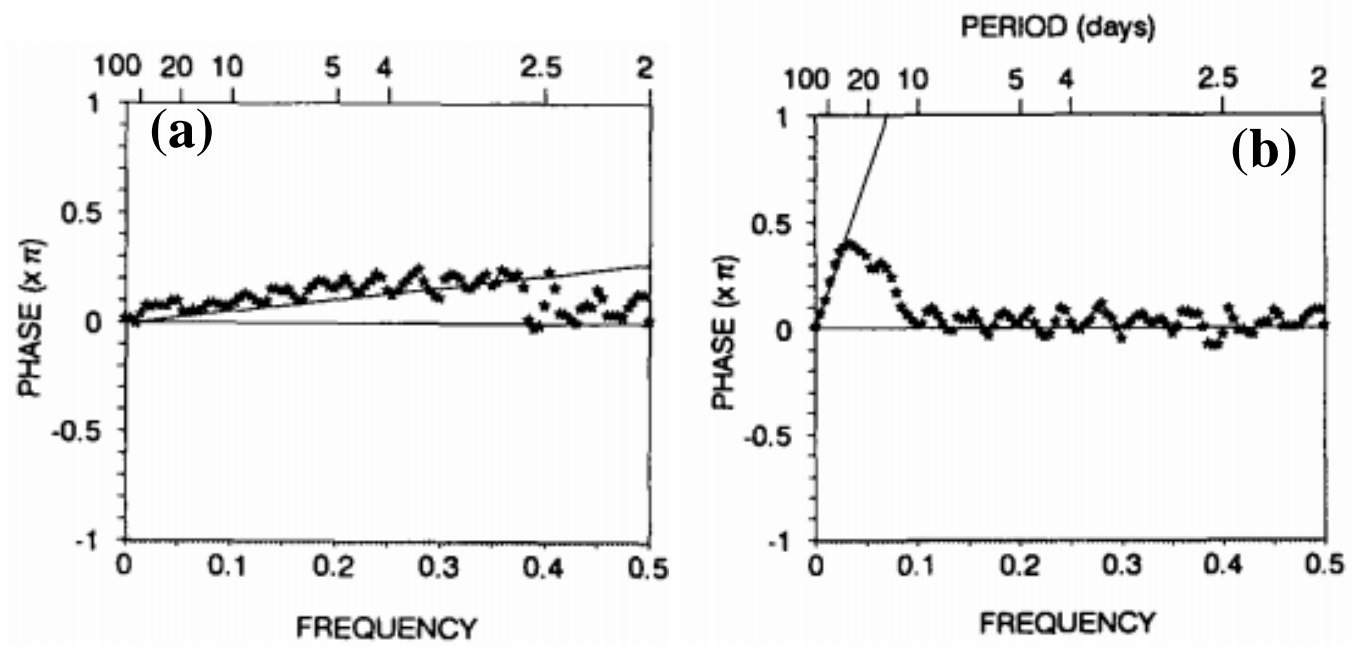

Gambar 6. Contoh grafik phase functions, (a) merupakan karst belum berkembang yang memiliki nilai phase lebih lambat daripada (b) yang merupakan karst berkembang (Padilla dan Pulido-Bosch, 1995).

\subsection{Coherency Functions}

Coherency functions menunjukkan kelinieran dari sistem karst. Karst yang telah berkembang akan mengubah input signal (curah hujan) langsung menjadi output signal (debit aliran) sehingga akan memiliki respons yang lebih linier dibandingkan karst yang belum berkembang (Gambar 7). Persamaan dari fungsi ini adalah sebagai berikut:
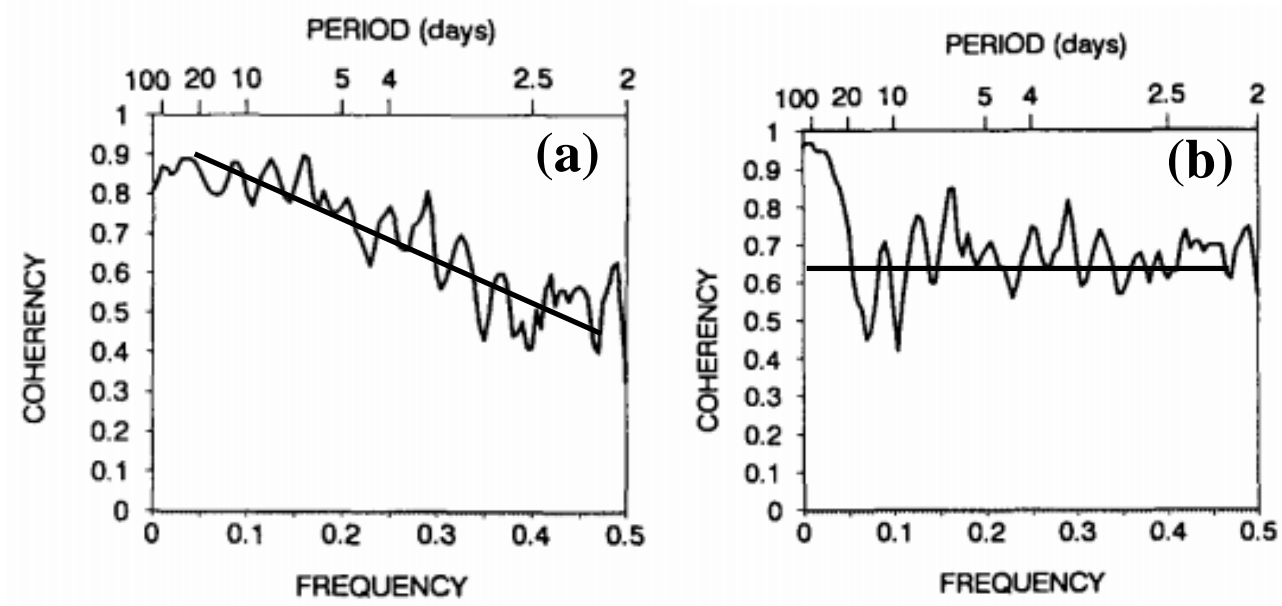

Gambar 7. Contoh grafik coherency: (a) merupakan karst belum berkembang yang memiliki tingkat kelinieran data kurang dari (b) yang merupakan karst berkembang (Padilla dan Pulido-Bosch, 1995) 


$$
C O_{x y}(f)=\frac{S_{x y}(f)}{\sqrt{S_{x}(f) S_{y}(f)}}
$$

\subsection{Gain-Functions}

Gain functions menunjukkan durasi dari aliran conduit, fissure, dan diffuse. Padilla dan Pulido-Bosch (1995) membuktikan bahwa gain yang bernilai satu menandakan berlakunya aliran diffuse, nilai 0,4 menunjukkan berlakunya aliran conduit, dan diantara nilai keduanya berlaku aliran fissure. Karst yang telah berkembang akan memiliki durasi aliran conduit, fissure, dan diffuse yang lebih cepat dibandingkan karst belum berkembang (Gambar 2.8). Persamaan dari fungsi ini adalah sebagai berikut:

$$
g_{x y}(f)=\frac{s_{x y}(f)}{s_{x}(f)}
$$

\section{Alat dan Bahan}

\subsection{Alat:}

1. Laptop

2. Software Ms.Excel untuk mengolah data dan membuat grafik.

3. Software XLSTAT (exstensi Ms.Excel) yang dapat di download pada link berikut https://www.xlstat.com/en/download.

\subsection{Bahan:}

1. Pasangan data debit aliran dengan curah hujan selama kurun waktu tertentu. Perhitungan pada tulisan ini menggunakan data pengukuran di Sistem Karst Pindul, Kec. Karangmojo, Kab. Gunungkidul. Data debit aliran dan curah hujan diukur pada dua lokasi, yaitu Gua Pindul sebagai outlet sistem karst dan Sinking Stream Kedungbuntung (Gambar 8). Data yang digunakan memiliki rentang 6 bulan (31 Desember 2016 - 30 Juni 2017). 


\section{PETA PENGGUNAAN LAHAN SISTEM DRAINASE KARST PINDUL}

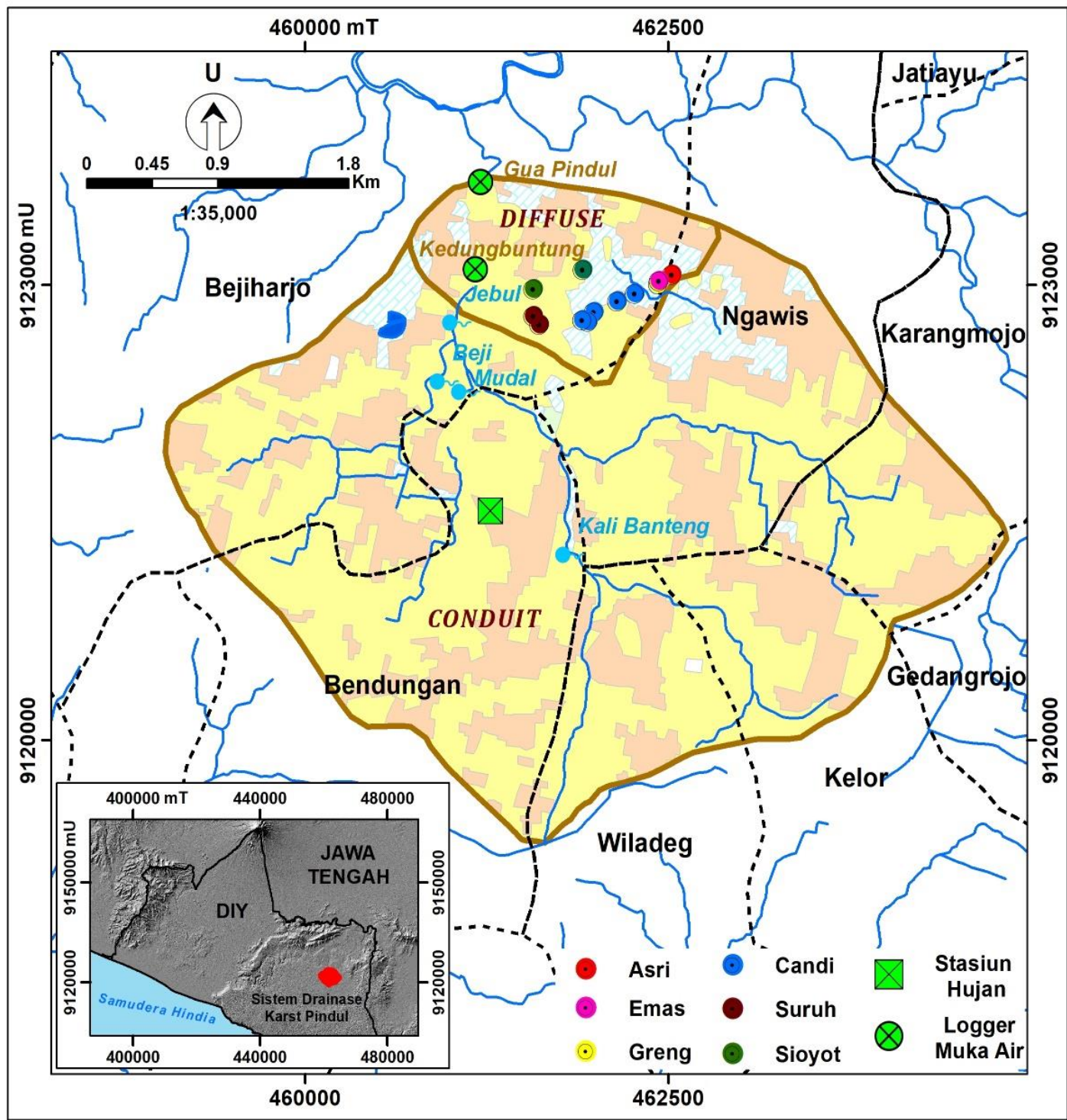

\begin{tabular}{|c|c|c|}
\hline \multirow{2}{*}{ Legenda: } & Penggunaan Lahan & Sumber: \\
\hline & & $\begin{array}{l}\text { 1. Peta Podes Gunungkidul Tahun } 2008 \\
\text { 2. Peta RBI Digital Tahun } 2004\end{array}$ \\
\hline . . . . . Ratac deca & Permukiman & \multirow{2}{*}{$\begin{aligned} \text { Sistem Koordinat: } & \begin{array}{l}\text { Universal } \\
\text { Mercator }\end{array}\end{aligned}$} \\
\hline Batas desa & Rumput & \\
\hline Sungai & Sawah irigasi & Datum: WGS 84 \\
\hline Sistem Karst Pindul & $\begin{array}{l}\text { Tegalan } \\
\text { Tubuh air }\end{array}$ & $\begin{aligned} \text { Dibuat oleh: } & \text { Afid Nurkholis } \\
& \text { Fakultas Geografi, UGM } \\
& \text { Tahun } 2017\end{aligned}$ \\
\hline
\end{tabular}

Gambar 8. Peta penggunaan lahan dan pemasangan alat Sistem Karst Pindul 


\section{Langkah Kerja}

\subsection{Installasi software XLSTAT}

1. Install master program XLSTAT yang telah didownload sebelumnya.

2. Apabila installasi berhasil maka ketika membuka Ms.Excel telah ada exstensi XLSTAT pada toolbar (Gambar 9).

3. Jalankan XLSTAT dengan melakukan klik pada "start XLSTAT” (Gambar 9).

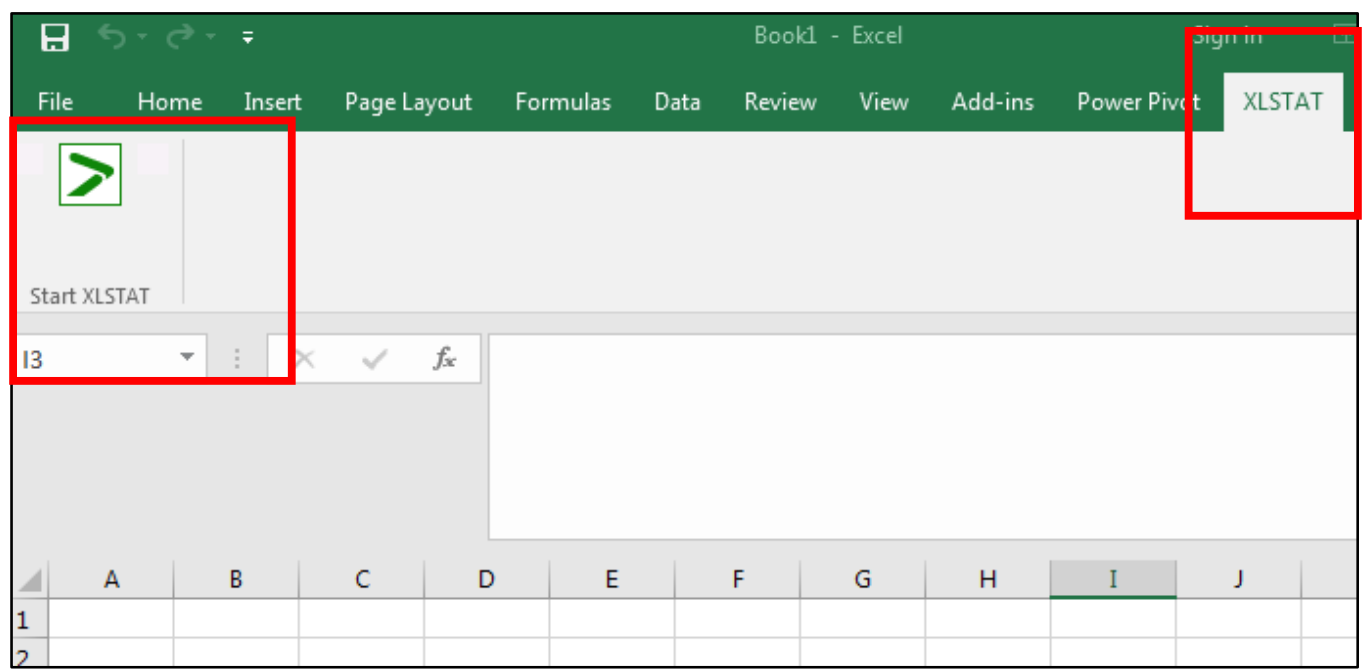

Gambar 9. Mengoperasikan software XLSTAT

4. XLSTAT yang siap digunakan akan memiliki tampilan seperti Gambar 10.

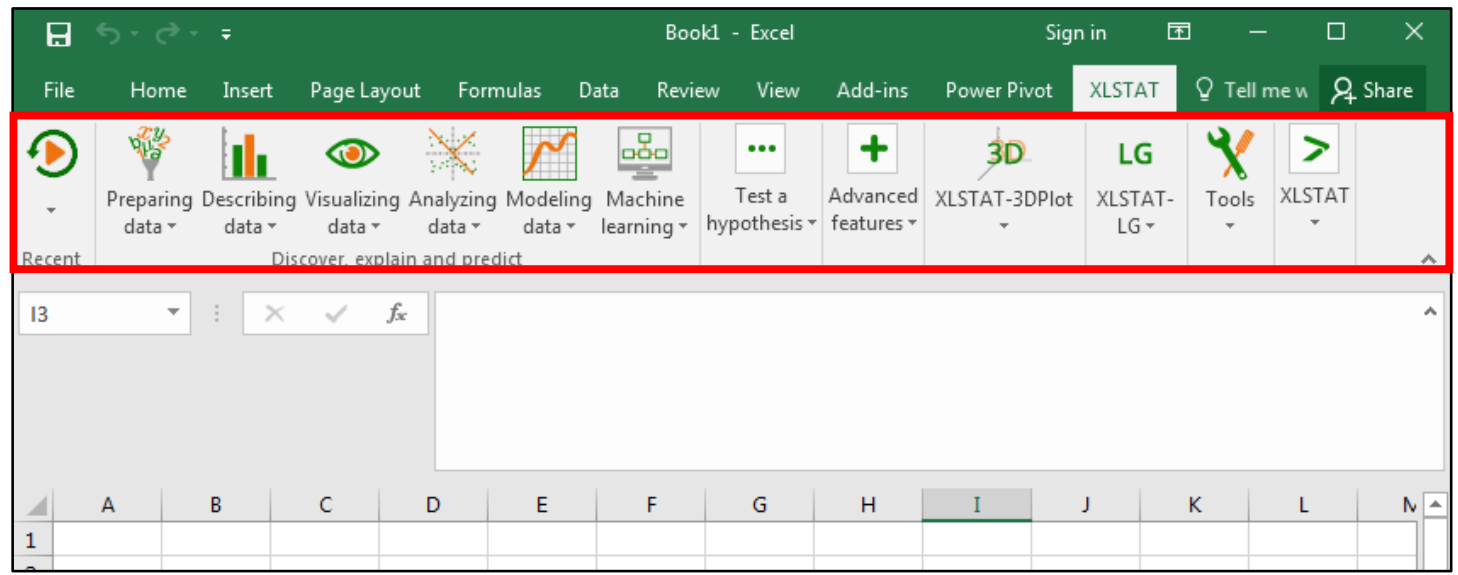

Gambar 10. Software XLSTAT yang siap digunakan

\subsection{Perhitungan Cross-Correlation}

1. Persiapkan pasangan data debit aliran dan curah hujan di software Ms.Excel (selama 6 bulan di tulisan ini) (Gambar 11). 


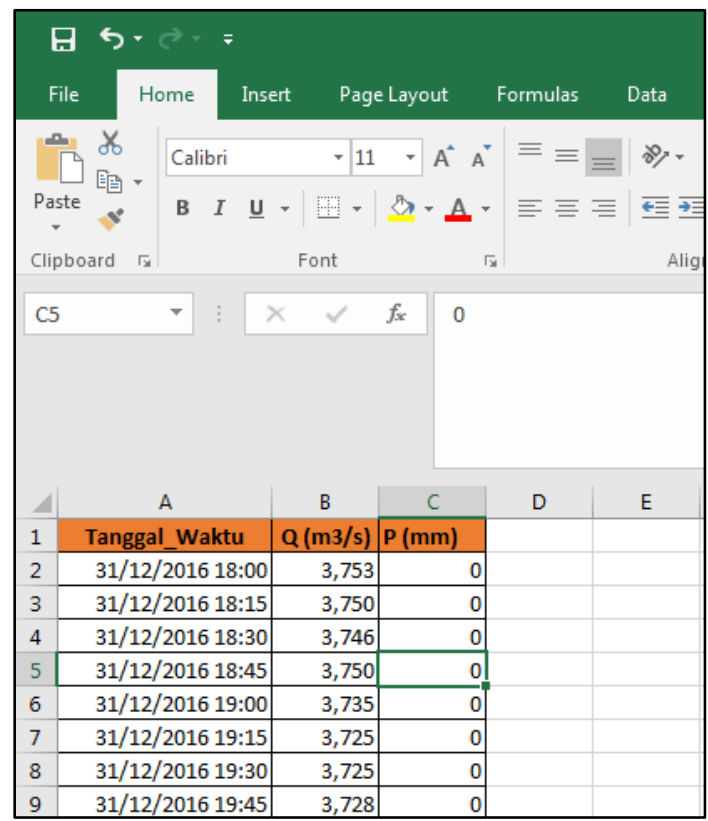

Gambar 11. Input pasangan data debit aliran dan hujan di Ms.Excel

2. Membuka modul cross-correlation di XLSTAT dengan cara klik Advance features >> Time series analysis >> Descriptive analysis (Gambar 12).

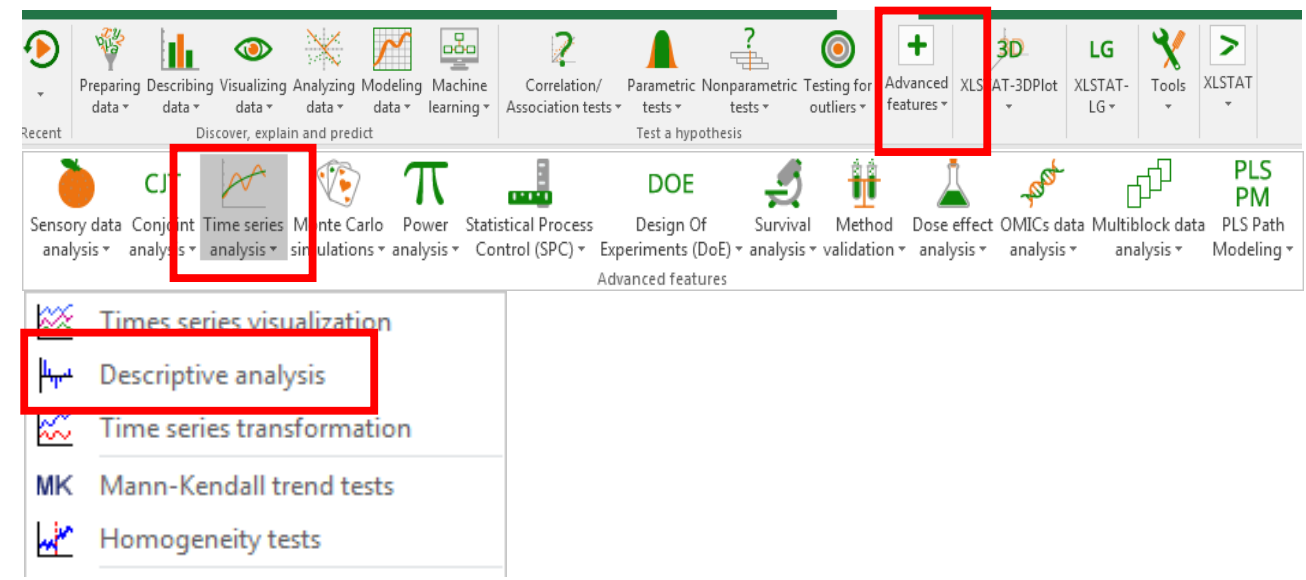

Gambar 12. Membuka modul cross-correlation

3. Modul cross-correlation nampak seperti Gambar 13. Series label menunjukkan apakah label data ikut dimasukkan dalam pemrosesan atau tidak. Time series diisi pasangan data debit aliran dan hujan.

4. Untuk melakukan input data, klik Time series kemudian blok series data debit dan curah hujan beserta labelnya (Gambar 13). 


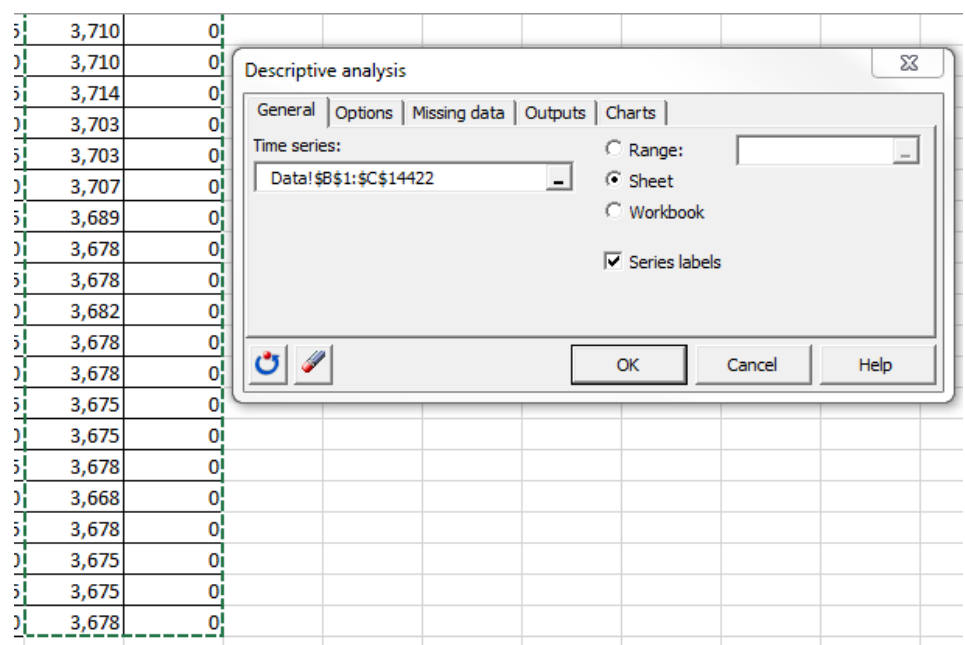

Gambar 13. Input data cross-correlation

5. Menentukan panjang waktu perhitungan (angka maksimal Time Lag $\left(\mathbf{T}_{\text {lag }}\right)$ ) dengan cara klik Options.

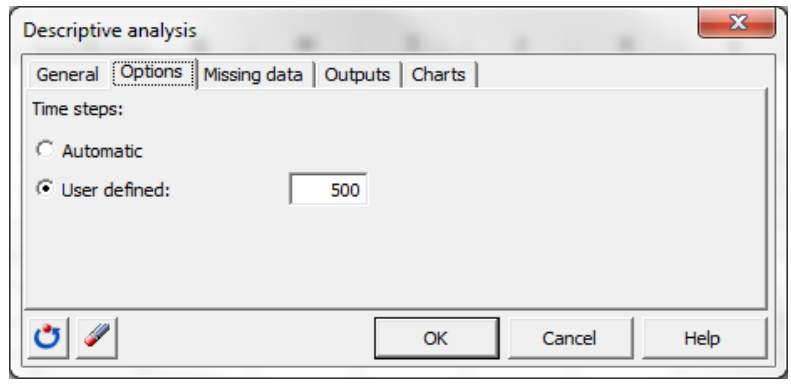

Gambar 14. Penentuan nilai maksimal Tlag

Jika ingin nilai tersebut otomatis, maka pilih Automatic. Pilih User defined untuk menentukan secara manual (500 pada perhitungan ini) (Gambar 14).

6. Memilih metode untuk menentukan cara apabila ada data yang rusak/hilang/tidak berpasangan, yaitu dengan klik Missing data (Gambar 15).

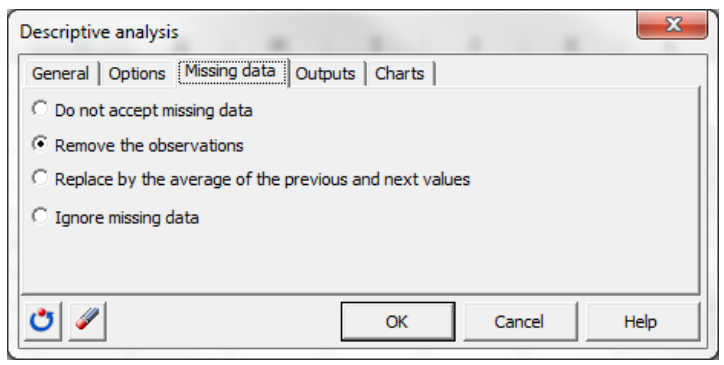

Gambar 15. Pemilihan metode pada data yang rusak

7. Pilih output dari analisis dengan cara klik Outputs (Gambar 16). Yang perlu dilakukan adalah mencentang Cross-correlations, memilih derajat kepercayaan 
(Confidence intervals, 95\% di perhitungan ini), dan mencentang White noise assumption karena hubungan debit aliran dan curah hujan diaanggap sebagai white noise.

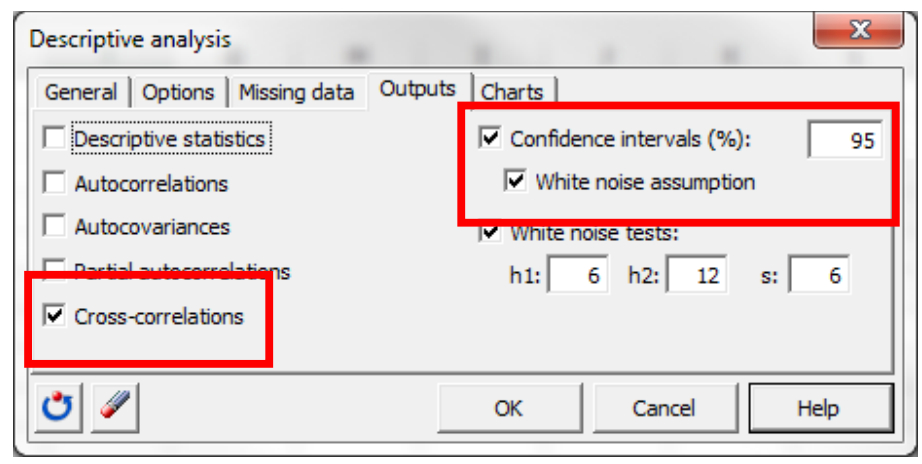

Gambar 16. Pemilihan output

8. Pilih output grafik yang ingin dihasilkan dengan klik Charts (Gambar 17). Grafik dapat dibuat secara terpisah menggunakan MS.Excel.

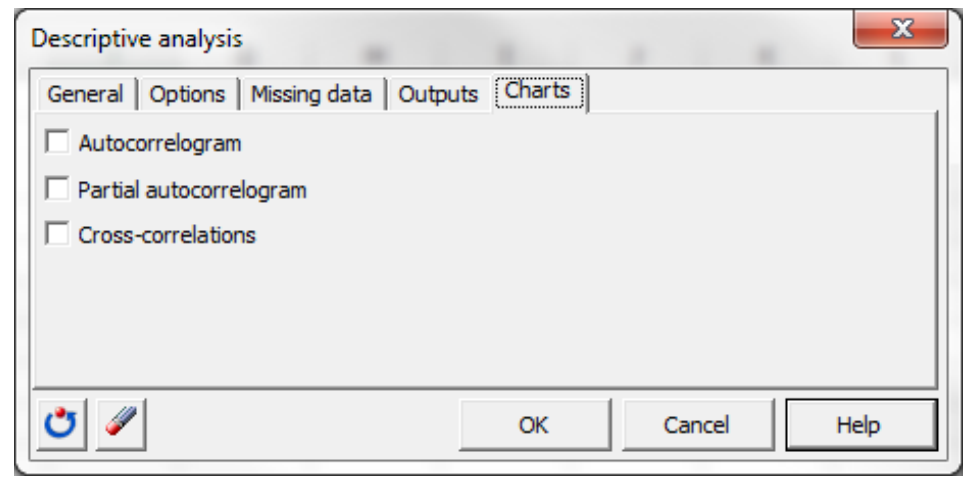

Gambar 17. Pemilihan output grafik

9. Klik Ok untuk menampilkan hasil. Hasil perhitungan akan muncul pada sheet terpisah (Gambar 18).

Cross-correlations $(\mathrm{Q}(\mathrm{m} 3 / \mathrm{s}) / \mathrm{P}(\mathrm{mm}))$ :

\begin{tabular}{|r|r|r|r|r|}
\hline Lag & Cross-correlation & Standard error & Lower bound $(95 \%)$ & Upper bound (95\%) \\
\hline-500 & 0,018 & 0,008 & $-0,016$ & 0,016 \\
\hline-499 & 0,017 & 0,008 & $-0,016$ & 0,016 \\
\hline-498 & 0,016 & 0,008 & $-0,016$ & 0,016 \\
\hline-497 & 0,014 & 0,008 & $-0,016$ & 0,016 \\
\hline-496 & 0,013 & 0,008 & $-0,016$ & 0,016 \\
\hline-495 & 0,012 & 0,008 & $-0,016$ & 0,016 \\
\hline-494 & 0,012 & 0,008 & $-0,016$ & 0,016 \\
\hline-493 & 0,011 & 0,008 & $-0,016$ & 0,016 \\
\hline-492 & 0,010 & 0,008 & $-0,016$ & 0,016 \\
\hline-491 & 0,010 & 0,008 & $-0,016$ & 0,016 \\
\hline-490 & 0,009 & 0,008 & $-0,016$ & 0,016 \\
\hline-489 & 0,009 & 0,008 & $-0,016$ & 0,016 \\
\hline-488 & 0,009 & 0,008 & $-0,016$ & 0,016 \\
\hline-487 & 0,009 & 0,008 & $-0,016$ & 0,016 \\
\hline
\end{tabular}

Gambar 18. Hasil cross-correlation 
10. Perhitungan diatas menggunakan data Gua Pindul. Untuk membandingkan analisis, perhitungan kali ini juga menggunakan data Sinking Stream Kedungbuntung. Untuk data yang berbeda, perhitungan dapat dilakukan dengan langkah 1-9 diatas.

11. Membuat grafik cross-correlation yang juga disebut cross-correlogram dengan cara membuat tabel berisi kolom Lag, cross-correlation Gua Pindul dan crosscorrelation Kedungbuntung (Gambar 19).

\begin{tabular}{|c|c|c|c|}
\hline 4 & A & B & C \\
\hline . & Lag & $\begin{array}{c}\text { Gua Pindul Cross- } \\
\text { correlation }\end{array}$ & \begin{tabular}{|c}
$\begin{array}{c}\text { Kedungbuntung Cross- } \\
\text { correlation }\end{array}$ \\
\end{tabular} \\
\hline ! & -500 & 0,018 & 0,024 \\
\hline 3 & -499 & 0,017 & 0,024 \\
\hline 1 & -498 & 0,016 & 0,026 \\
\hline ; & -497 & 0,014 & 0,029 \\
\hline ; & -496 & 0,013 & 0,030 \\
\hline ' & -495 & 0,012 & 0,030 \\
\hline 3 & -494 & 0,012 & 0,030 \\
\hline 1 & -493 & 0,011 & 0,030 \\
\hline 0 & -492 & 0,010 & 0,029 \\
\hline 1 & -491 & 0,010 & 0,028 \\
\hline 2 & -490 & 0,009 & 0,028 \\
\hline 3 & -489 & 0,009 & 0,028 \\
\hline 4 & -488 & 0,009 & 0,029 \\
\hline 5 & -487 & 0,009 & 0,029 \\
\hline 6 & -486 & 0,009 & 0,028 \\
\hline 7 & -485 & 0,009 & 0,027 \\
\hline 8 & -484 & 0,008 & 0,027 \\
\hline 9 & -483 & 0,007 & 0,026 \\
\hline 0 & -482 & 0,007 & 0,026 \\
\hline
\end{tabular}

Gambar 19. Input pembuatan cross-correlogram

12. Blok ketiga kolom, kemudian klik Insert $>>$ Scatter $>>$ Scatter with smooth line (Gambar 20).

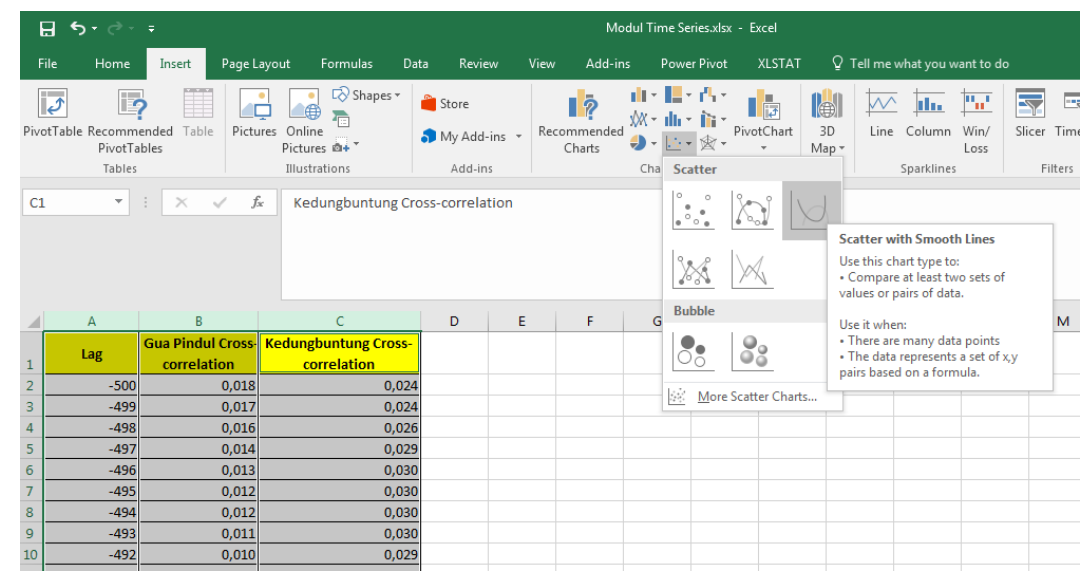

Gambar 20. Pembuatan cross-correlogram 
13. Cros-correlogam nampak seperti Gambar 21. Kedua lokasi memiliki Puncak grafik yang sama, yaitu pada $T_{\text {lag }}$ jam ke-7. Nilai tersebut perlu dikalikan dengan 15 karena pencatatan debit dan curah hujan dilakukan setiap interval 15 menit. $T_{\text {lag }}$ Gua Pindul dan Kedungbuntung memiliki waktu 1 jam 45 menit. Nilai ini merupakan rerata pada seluruh kejadian banjir. Nilai ini juga identik dengan $T_{\text {lag }}$ pada hidrograf banjir.

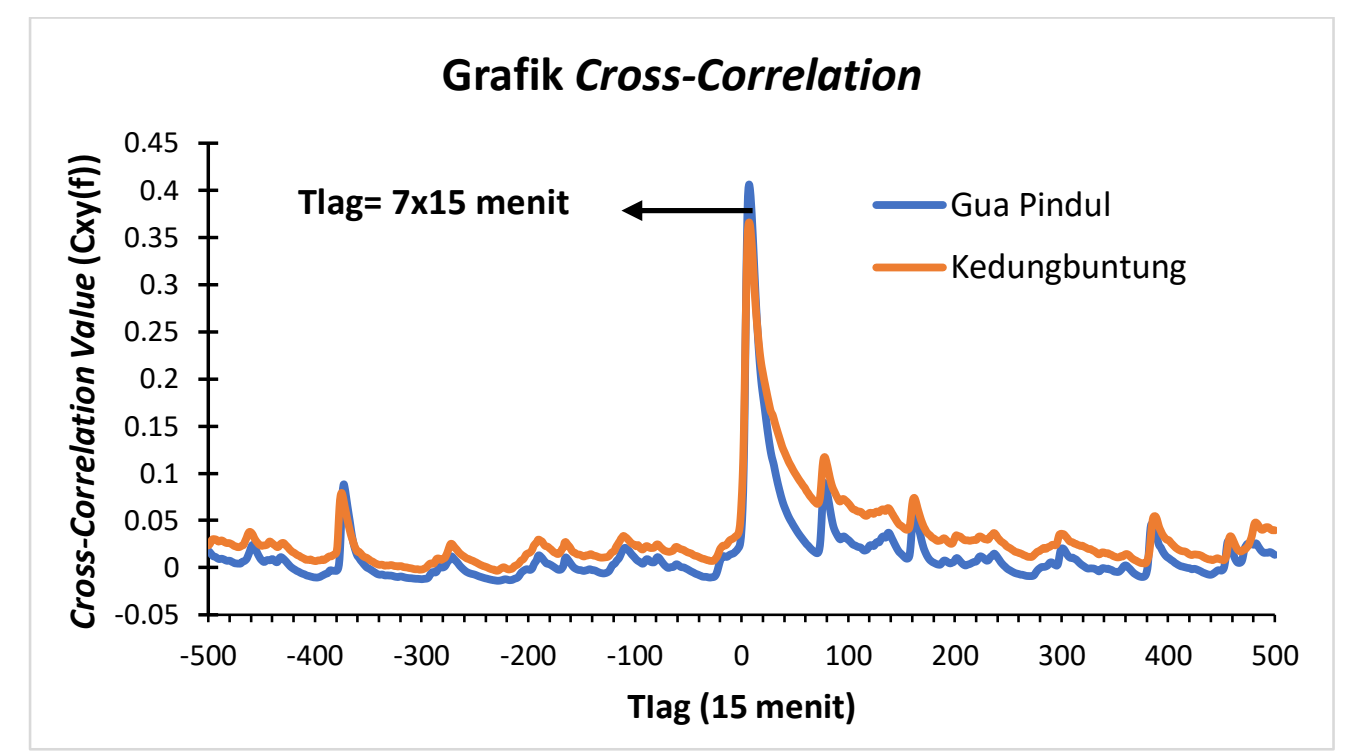

Gambar 21. Cross-collerogram Gua Pindul dan Kedungbuntung

14. Grafik cross-correlation juga dapat digunakan untuk menganalisis pelepasan aliran fissure. Rerata durasi aliran fissure diperoleh melalui nilai initially sharp decline pada grafik cross-correlation. Konsep ini identik dengan resesi aliran fissure (Gambar 22). Gua Pindul dan Kedungbuntung memiliki rerata pelepasan aliran fissure 4 jam.

\subsection{Perhitungan Auto-Correlation}

1. Persiapkan input data dan lakukan proses yang sama seperti perhitungan crosscorrelation pada langkah 1-6.

2. Pilih output dengan cara klik Outputs (Gambar 23). Centang Autocorrelations, Confidence intervals (95\% di perhitungan ini), dan White noise assumptions.

3. Pilih grafik yang ingin dihasilkan. Pembuaran grafik dapat dilakukan seara terpisah pada Ms.Excel (Gambar 24). 
4. Klik OK untuk menampilkan hasil perhitungan auto-correlation (Gambar 25). Untuk membandingkan hasil, hitung data lain dengan cara mengikuti langkah 1-3 diatas. Perhitungan ini menggunakan data Gua Pindul dan Kedungbuntung.

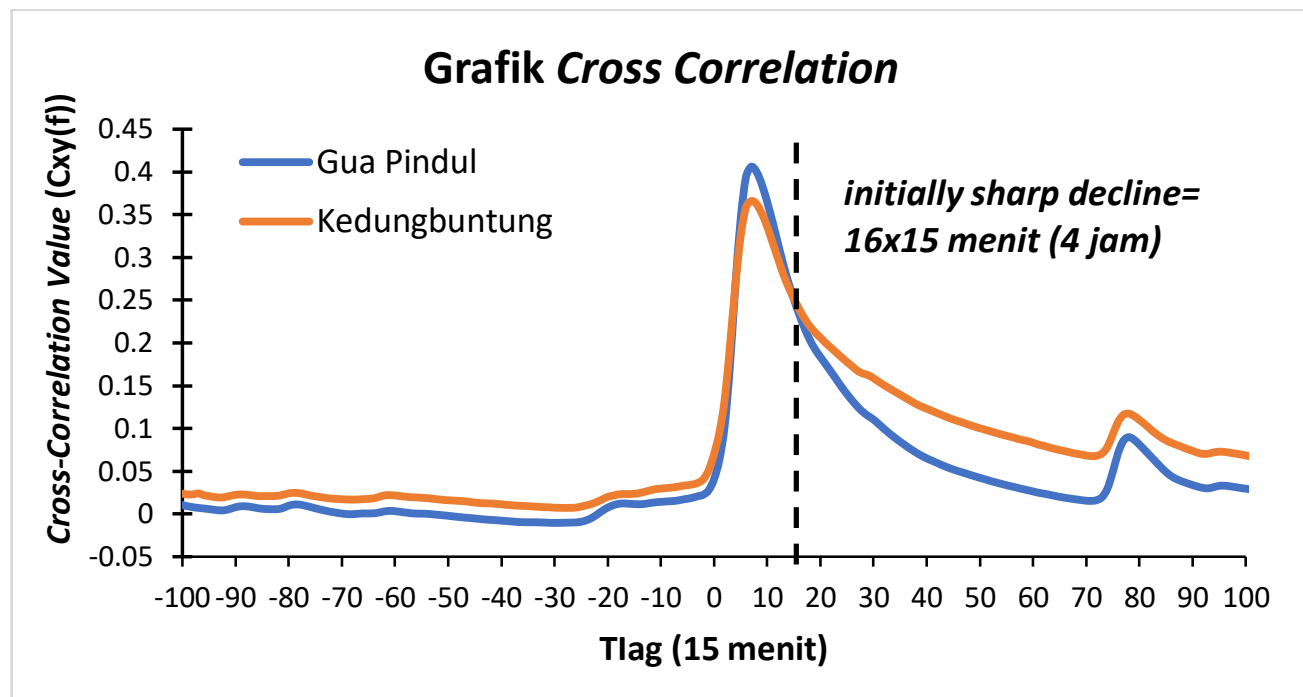

Gambar 22. Initially Sharp Decline dari Grafik Cross-Correlation

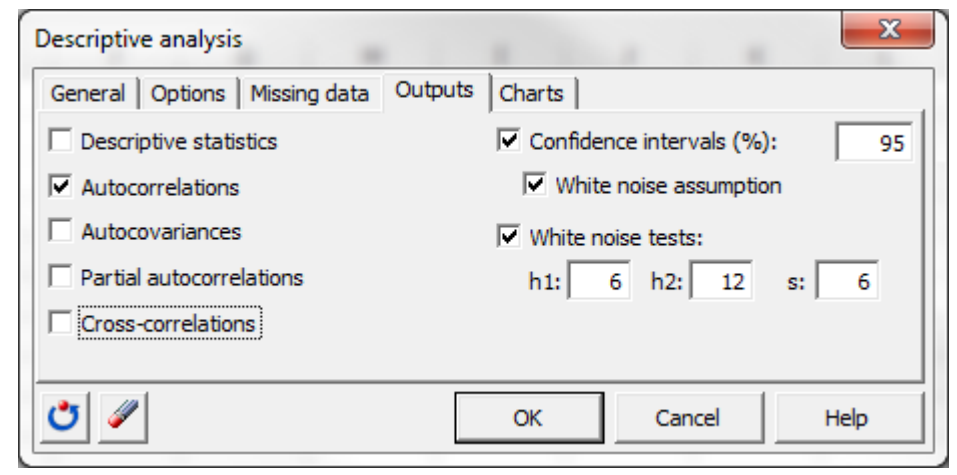

Gambar 23. Pemilihan output

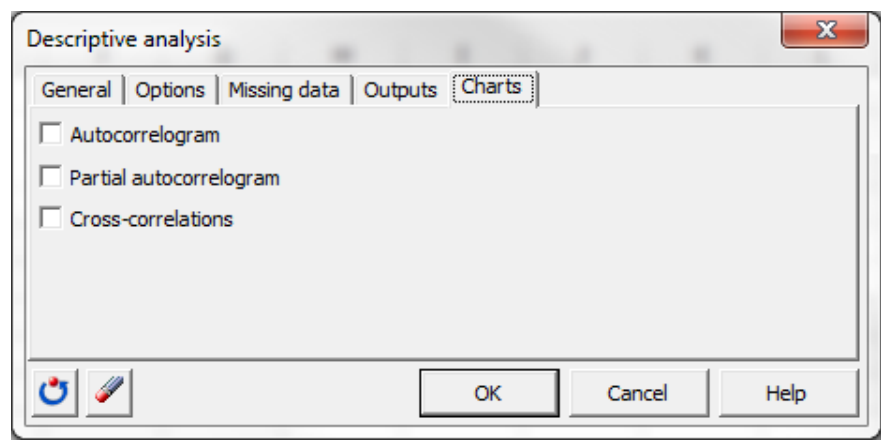

Gambar 24. Pemilihan hasil grafik 


\begin{tabular}{|r|r|r|r|r|}
\hline \multicolumn{2}{|l|}{ Descriptive analysis $(\mathrm{Q}(\mathrm{m} 3 / \mathrm{s}))$ : } & \\
\hline Lag & Autocorrelation & Standard error & Lower bound $(95 \%)$ & Upper bound (95\%) \\
\hline 0 & 1,000 & 0,000 & & \\
\hline 1 & 0,981 & 0,008 & $-0,016$ & 0,016 \\
\hline 2 & 0,934 & 0,008 & $-0,016$ & 0,016 \\
\hline 3 & 0,872 & 0,008 & $-0,016$ & 0,016 \\
\hline 4 & 0,805 & 0,008 & $-0,016$ & 0,016 \\
\hline 5 & 0,738 & 0,008 & $-0,016$ & 0,016 \\
\hline 6 & 0,675 & 0,008 & $-0,016$ & 0,016 \\
\hline 7 & 0,616 & 0,008 & $-0,016$ & 0,016 \\
\hline 8 & 0,563 & 0,008 & $-0,016$ & 0,016 \\
\hline 9 & 0,516 & 0,008 & $-0,016$ & 0,016 \\
\hline 10 & 0,475 & 0,008 & $-0,016$ & 0,016 \\
\hline 11 & 0,439 & 0,008 & $-0,016$ & 0,016 \\
\hline 12 & 0,407 & 0,008 & $-0,016$ & 0,016 \\
\hline 13 & 0,379 & 0,008 & $-0,016$ & 0,016 \\
\hline
\end{tabular}

Gambar 25. Hasil auto-correlation

5. Membuat tabel berisi hasil auto-correlation (Gua Pindul dan Kedungbuntung) di Ms Excel (Gambar 26).

\begin{tabular}{c|c|c|c|}
\multicolumn{2}{|c|}{ A } & B & C \\
\hline & Lag & $\begin{array}{c}\text { Gua Pindul } \\
\text { Autocorrelation }\end{array}$ & $\begin{array}{c}\text { Kedungbuntung } \\
\text { Autocorrelation }\end{array}$ \\
\hline 1 & 0 & 1,000 & 1,000 \\
\hline 2 & 0,981 & 0,988 \\
\hline 3 & 1 & 0,934 & 0,960 \\
\hline 4 & 2 & 0,872 & 0,924 \\
\hline 5 & 3 & 0,805 & 0,885 \\
\hline 6 & 4 & 0,738 & 0,845 \\
\hline 7 & 5 & 0,675 & 0,807 \\
\hline 8 & 6 & 0,616 & 0,771 \\
\hline 9 & 7 & 0,563 & 0,739 \\
\hline 10 & 8 & 0,516 & 0,709 \\
\hline 11 & 9 & 0,475 & 0,684 \\
\hline 12 & 10 & &
\end{tabular}

Gambar 26. Auto-correlation Gua Pindul dan Kedungbuntung

6. Membuat grafik auto-correlation atau yang biasa disebut correlogram dengan cara blok ketiga kolom kemudian klik Insert $>>$ Scatter $>>$ Scatter with smooth line (Gambar 27). 


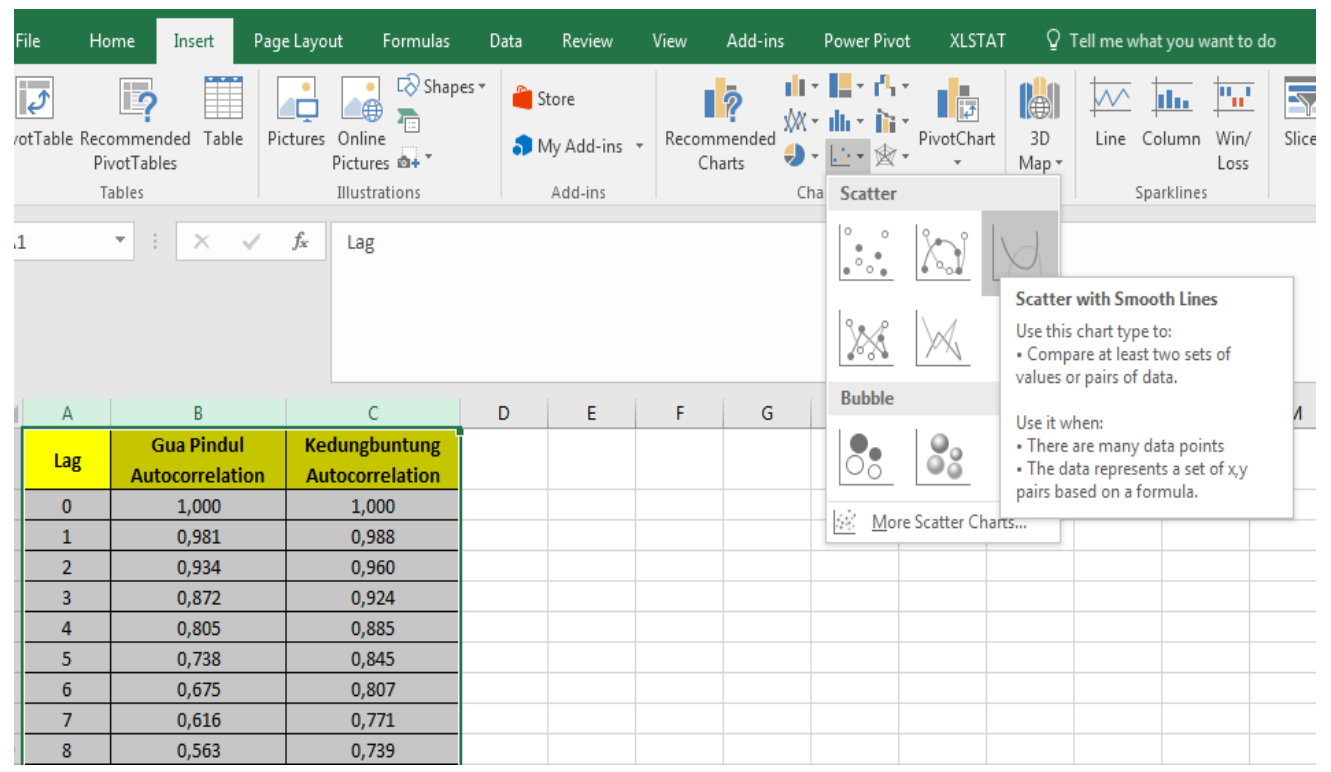

Gambar 27. Pembuatan correlogram

7. Correlogram (Gambar 28) dapat digunakan untuk menghitung rerata durasi pelepasan komponen diffuse. Konsep ini identik dengan resesi komponen basefelow atau aliran diffuse.

8. Untuk menghitung durasi tersebut, tentukan waktu dimana $\mathrm{C}(\mathrm{k})$ mencapai predetermined value. Nilai ini dihitung menggunakan persamaan 4 yang telah dijelaskan diatas. Banyak data yang digunakan dalam perhitungan ini adalah 14.391 baik di Gua Pindul maupun Kedungbuntung sehingga $C(k)=2 /\left(14391^{\wedge} 0,5\right)=0,02$.

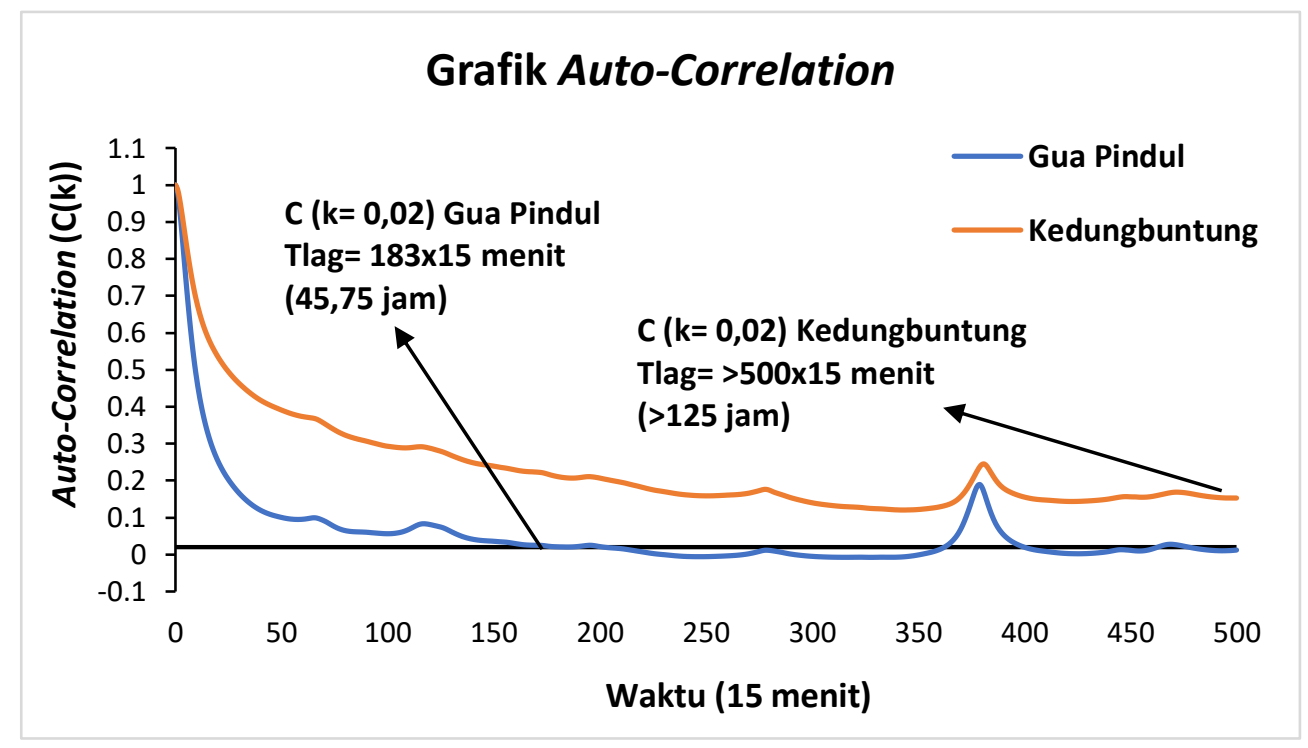

Gambar 28. Correlogram Gua Pindul dan Kedungbuntung 
9. Gambar 28 menunjukkan bahwa Gua Pindul mencapai $\mathrm{C}(\mathrm{k}=0,02)$ pada waktu 18 sehingga memiliki rerata pelepasa aliran diffuse $18 \times 15$ menit $=45,75 \mathrm{jam}$. Sementara itu, Kedungbuntung belum mencapai nilai $\mathrm{C}(\mathrm{k}=0,02)$ pada waktu makasimal correlogram (500) sehingga Kedungbuntung memiliki rerata durasi pelepasan aliran diffuse $>500 \times 15$ menit (>125 jam).

10. Correlogram juga dapat digunakan untuk mencari rerata durasi aliran fissure. Rerata durasi aliran fissure diperoleh melalui nilai initially sharp decline pada grafik auto-correlation. Konsep ini identik dengan resesi aliran fissure (Gambar 29). Kedua lokasi mengalami initially sharp decline pada waktu 10 sehingga memiliki rerata durasi pelepasan aliran fissure 2,5 jam.

\section{Grafik Auto-Correlation}

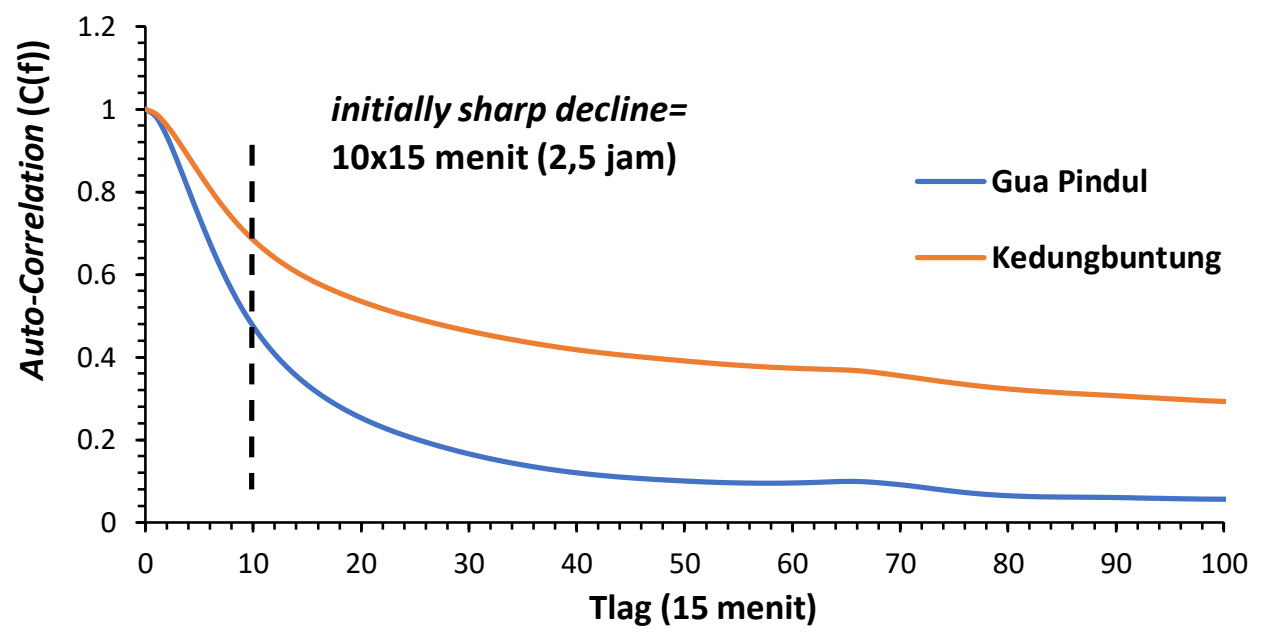

Gambar 29. Initially sharp decline pada correlogram

\subsection{Perhitungan Spectral Analysis}

Spectal analysis mencakup spectral density, cross-amplitude, phase

function, coherency function, gain function. Perhitungan spectal analysis adalah sebagai berikut:

1. Persiapkan input data berupa series pasangan data debit dan curah hujan (Gambar 30). Spectral analysis merupakan analisis frekuensi sehingga kolom debit diletakkan berkebalikan dengan analisis yang berdasarkan waktu (crosscorrelation dan auto-correlation). Kolom debit berada di sebelah kanan data hujan. 
2. Membuka modul analisis spectral analysis dengan cara klik Advance features $>>$ Time series analysis >> Spectral analysis (Gambar 31).

\begin{tabular}{|c|c|c|c|c|}
\hline$\Delta$ & $A$ & B & C & D \\
\hline 1 & Tanggal_Waktu & $\mathbf{P}(\mathrm{mm})$ & $\mathrm{Q}(\mathrm{m} 3 / \mathrm{s})$ & \\
\hline 2 & $31 / 12 / 2016$ 18:00 & 0 & 3,753 & \\
\hline 3 & $31 / 12 / 201618: 15$ & 0 & 3,750 & \\
\hline 4 & $31 / 12 / 201618: 30$ & 0 & 3,746 & \\
\hline 5 & $31 / 12 / 201618: 45$ & 0 & 3,750 & \\
\hline 6 & $31 / 12 / 201619: 00$ & 0 & 3,735 & \\
\hline 7 & $31 / 12 / 2016$ 19:15 & 0 & 3,725 & \\
\hline 8 & $31 / 12 / 201619: 30$ & 0 & 3,725 & \\
\hline 9 & $31 / 12 / 201619: 45$ & 0 & 3,728 & \\
\hline 10 & $31 / 12 / 201620: 00$ & 0 & 3,732 & \\
\hline 11 & $31 / 12 / 201620: 15$ & 0 & 3,725 & \\
\hline 12 & $31 / 12 / 201620: 30$ & 0 & 3,725 & \\
\hline 13 & $31 / 12 / 201620: 45$ & 0 & 3,732 & \\
\hline 14 & $31 / 12 / 201621: 00$ & 0 & 3,732 & \\
\hline 15 & $31 / 12 / 201621: 15$ & 0 & 3,725 & \\
\hline 16 & $31 / 12 / 201621: 30$ & 0 & 3,728 & \\
\hline 17 & $31 / 12 / 2016$ 21:45 & 0 & 3,721 & \\
\hline 18 & $31 / 12 / 201622: 00$ & 0 & 3,717 & \\
\hline 19 & $31 / 12 / 201622: 15$ & 0 & 3,717 & \\
\hline
\end{tabular}

Gambar 30. Input data spectral analysis

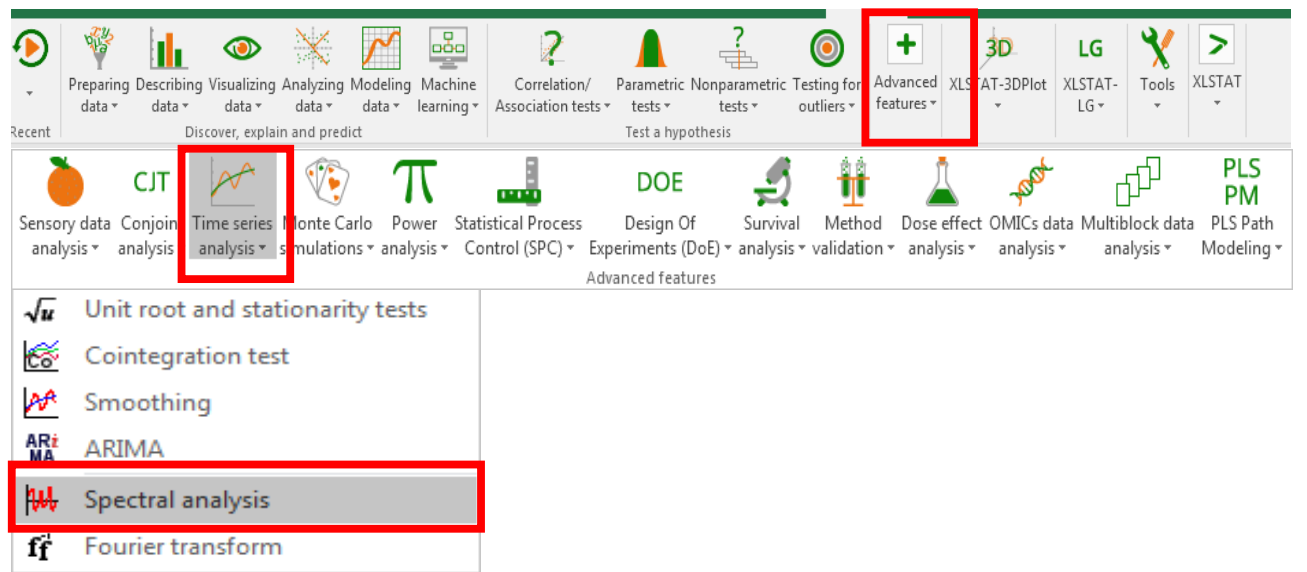

Gambar 31. Membuka modul spectral analysis

3. Melakukan input data dengan cara klik General $>>$ isi Time series dengan cara blok series data debit dan hujan >> isi Date data dengan cara blok tanggal/waktu data. Apabila Series labels dicentang, ketika melakukan pengeblokan data (pemilihan data) label data harus diikutsertakan (Gambar 32). 
4. Memilih pengolahan terhadap data yang rusak/tidak berpasangan dengan cara klik Missing data (Gambar 33).
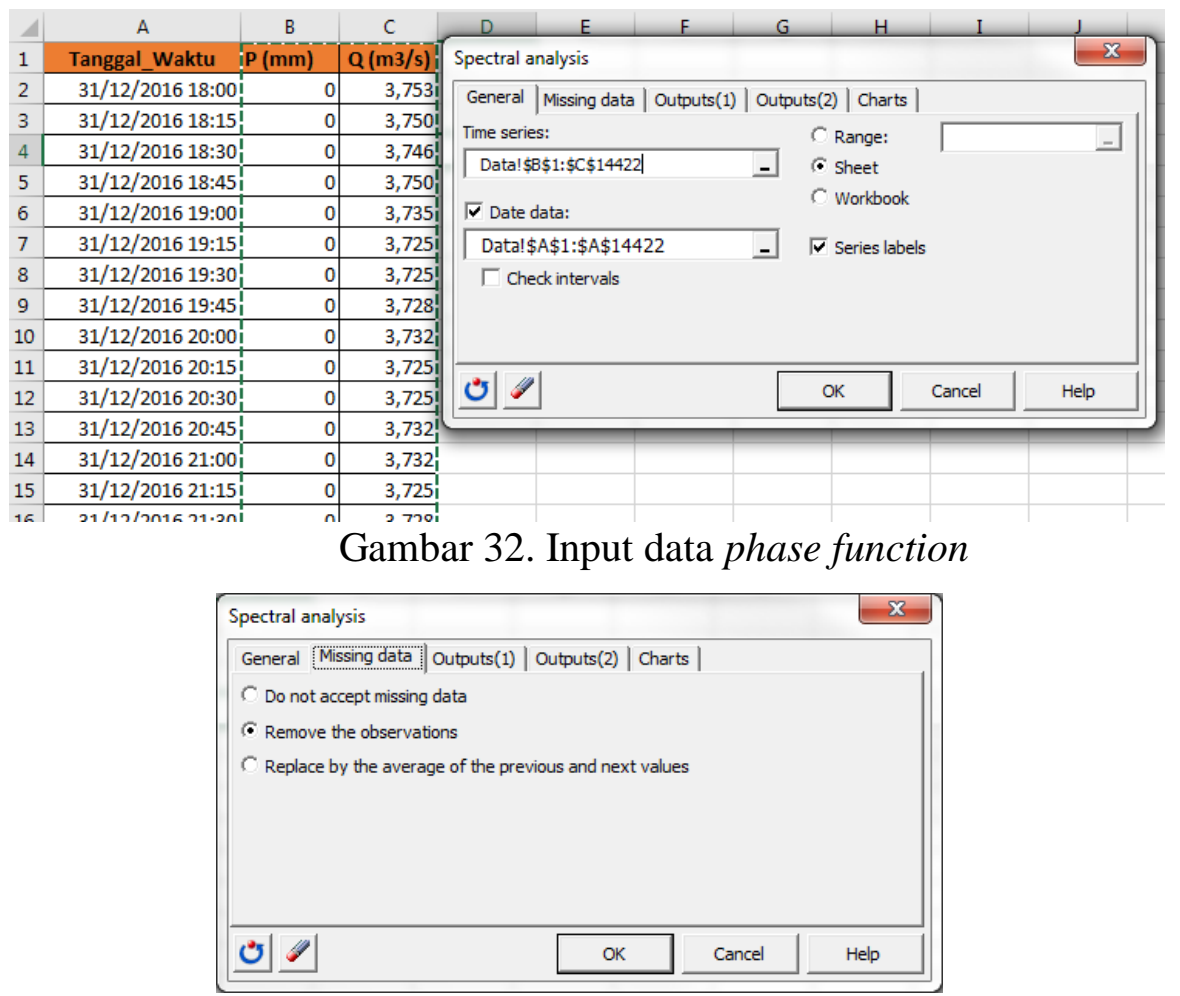

Gambar 33. Pemilihan metode terhadap data yang rusak

5. Memilih output perhitungan dengan cara klik Outputs (1). Centang White noise test, Amplitude, Phase, Spectral density. Kemudian, memilih metode analisis pada Kernel weighting (Gambar 34).

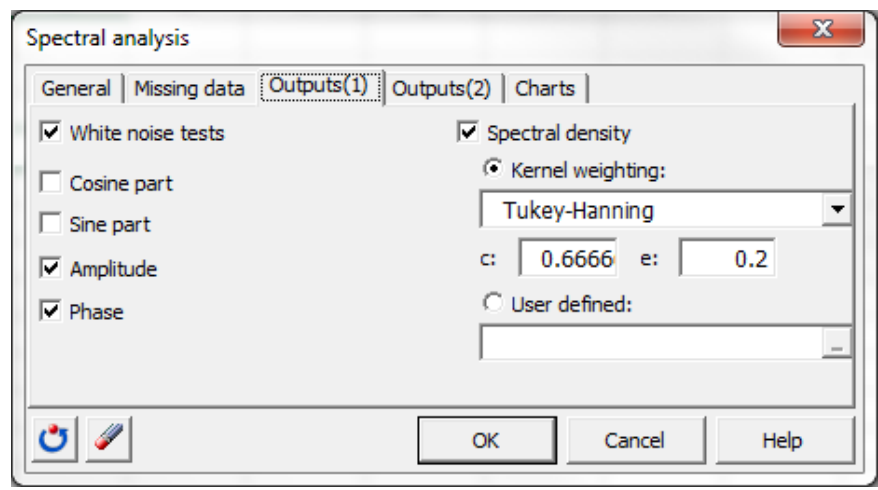

Gambar 34. Memilih output tahap 1

6. Memilih output tahap 2 dengan cara klik Outputs (2). Centang Cross-spectrum, Cospectrum, Quadrature spectrum, Squared coherency (Gambar 35). 


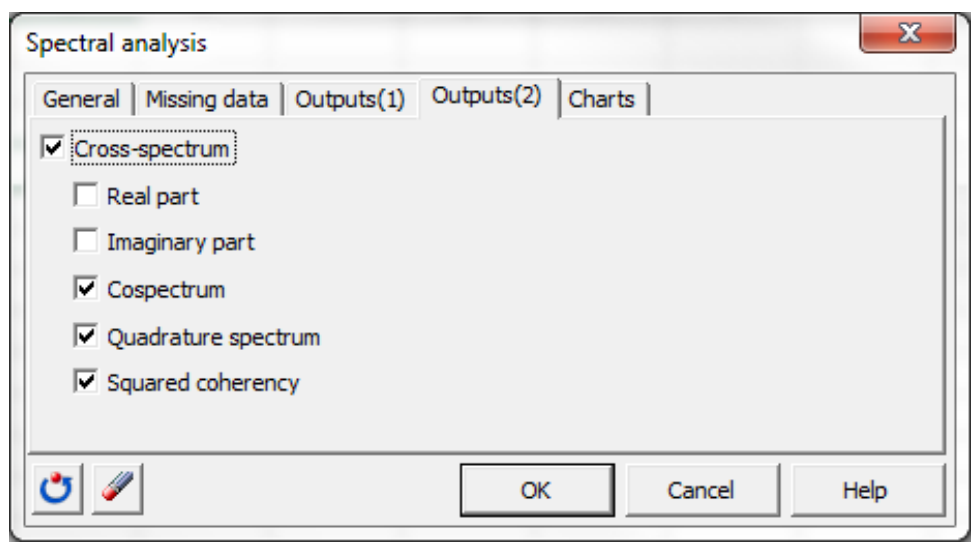

Gambar 35. Pemilihan output tahap 2

7. Memilih output grafik dengan cara klik Charts. Pembuatan grafik dapat dilakukan terpisah menggunakan Ms.Excel (Gambar 36). Tulisan ini membuat grafik terpisah menggunakan Ms.Excel.

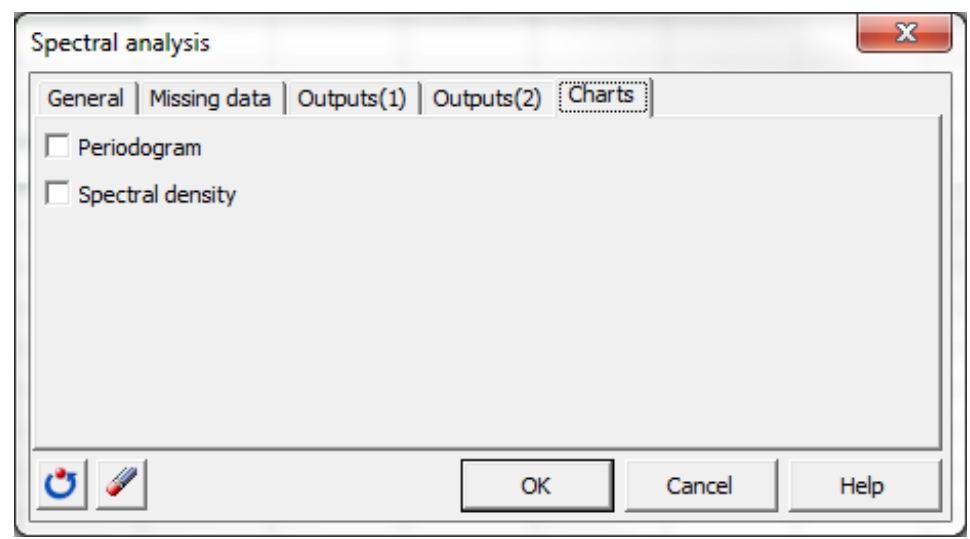

Gambar 36. Pemilihan output grafik

8. Klik OK untuk menampilkan hasil perhitungan. Hasil ini terdiri dari spectral analysis data hujan-debit serta cross-spectral analysis data hujan-debit (Gambar 37).

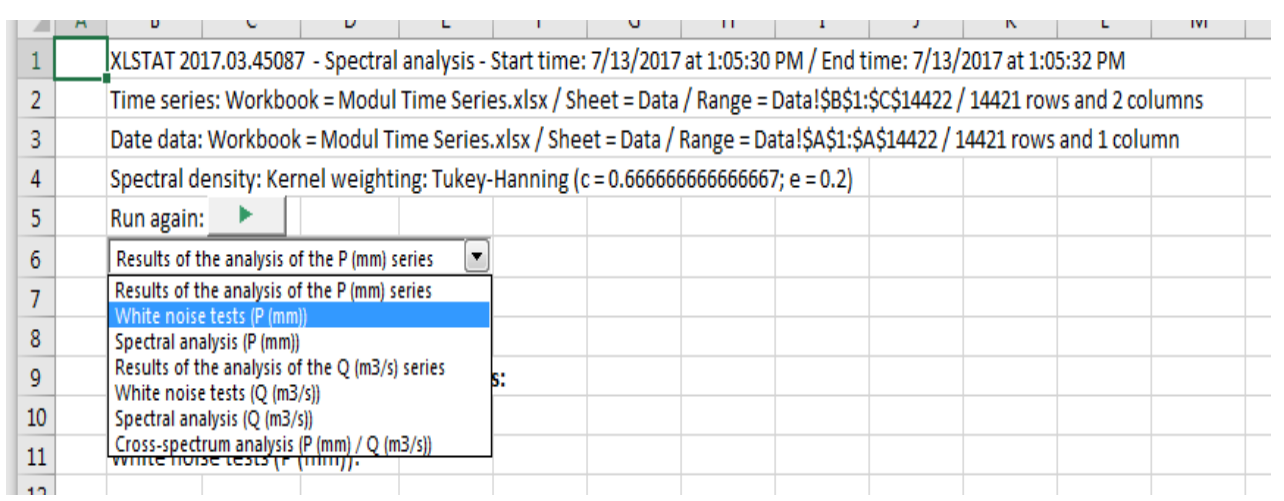

Gambar 37. Hasil perhitungan spectral analysis 
9. Lakukan langkah 1-8 pada data lain untuk perbandingan hasil (perhitungan ini menggunakan data Gua Pindul dan Sinking Stream Kedungbuntung).

\subsection{Perhitungan Phase Functions}

1. Mencari hasil perhitungan phase functions dari hasil perhitungan spectral analysis yang telah dijelaskan diatas. Perhitungan phase functions berada di Tabel Crossspectrum analysis (tabel ini biasanya terletak paling bawah dari hasil spectral analysis) (Gambar 38).

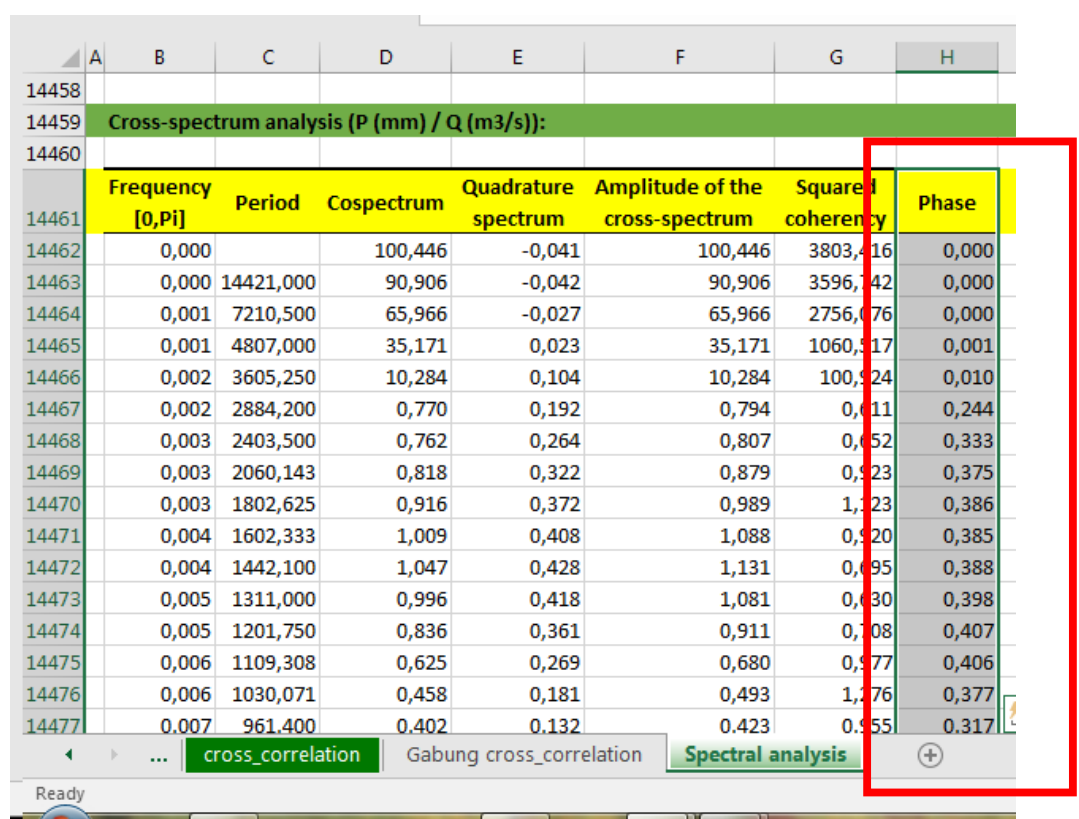

Gambar 38. Hasil perhitungan phase function yang ada di hasil perhitungan spectral analysis

2. Salin hasil phase functions dan frekuensi ke dalam sheet baru (Gambar 39).

\begin{tabular}{l|r|r|r|}
\hline \multicolumn{1}{|c|}{ A } & \multicolumn{1}{c|}{ B } & \multicolumn{1}{c|}{ C } \\
& $\begin{array}{c}\text { Frequency } \\
\text { [0,Pi] }\end{array}$ & $\begin{array}{c}\text { Gua } \\
\text { Pindul } \\
\text { Phase }\end{array}$ & $\begin{array}{r}\text { Kedungbuntung } \\
\text { Phase }\end{array}$ \\
\hline 2 & 0,000 & 0,000 & $-0,002$ \\
\hline 3 & 0,000 & 0,000 & $-0,001$ \\
\hline 4 & 0,001 & 0,000 & 0,000 \\
\hline 5 & 0,001 & 0,001 & 0,003 \\
\hline 6 & 0,002 & 0,010 & 0,022 \\
\hline 8 & 0,002 & 0,244 & 0,268 \\
\hline 9 & 0,003 & 0,333 & 0,367 \\
\hline 10 & 0,003 & 0,375 & 0,427 \\
\hline 11 & 0,003 & 0,386 & 0,460 \\
\hline 12 & 0,004 & 0,385 & 0,475 \\
\hline 13 & 0,004 & 0,388 & 0,485 \\
\hline 14 & 0,005 & 0,398 & 0,484 \\
\hline 15 & 0,005 & 0,407 & 0,472 \\
\hline
\end{tabular}

Gambar 39. Phase functions Gua Pindul dan Kedungbuntung 
3. Membuat grafik phase functions dengan cara blok ketiga kolom kemudian klik Insert $>$ Scatter $>>$ Scatter with smooth line (sama dengan langkah 6 perhitungan auto-correlation).

4. Atur rentang sumbu $\mathbf{x}$ (frekuensi) agar keliniearan terlihat. Phase functions merupakan perhitungan yang menunjukkan perbedaan signal antara input (hujan) dan output (debit aliran). Perbedaan frekuensi tersebut menyebabkan adanya grafik yang linier (Gambar 40).

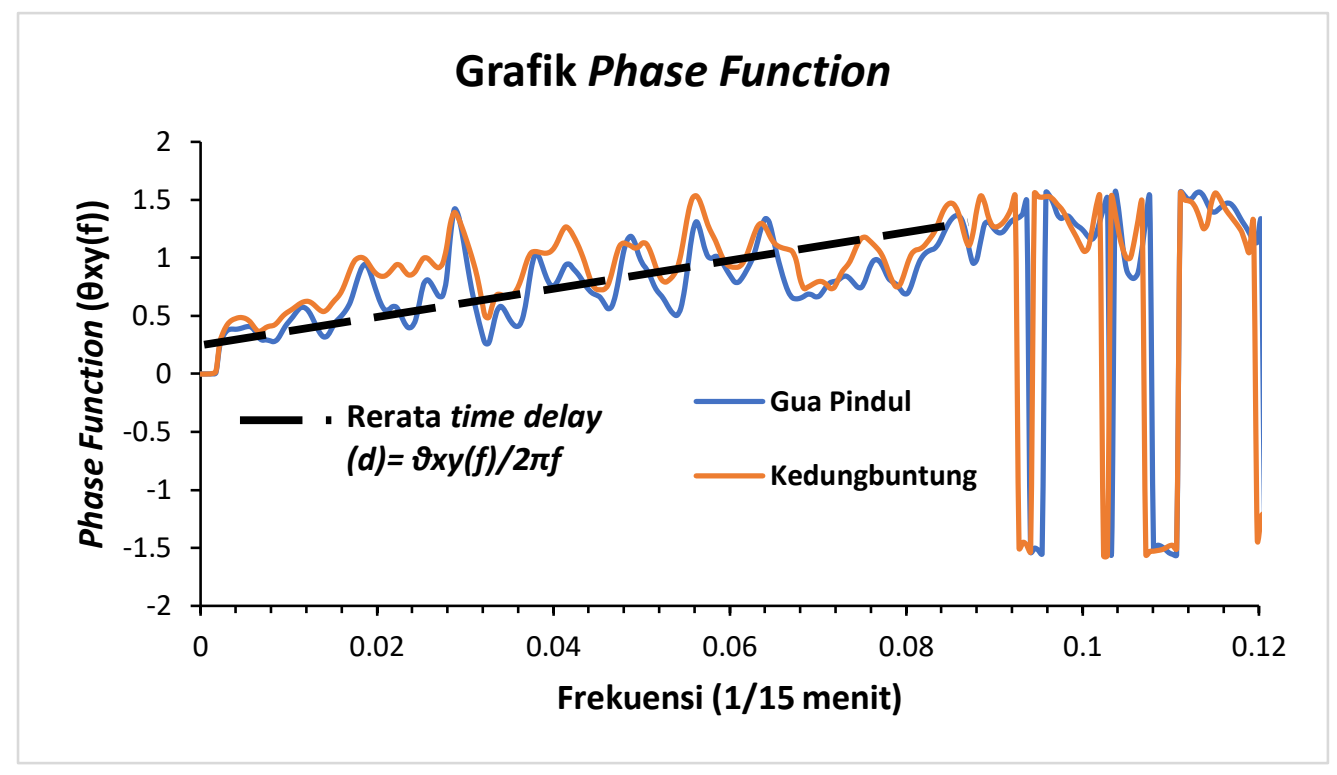

Gambar 40. Phase functions Gua Pindul dan Kedungbuntung

5. Gambar 40 menunjukkan phase functions mengalami kelinieran pada frekuensi 0,001-0,094. Grafik tersebut selanjutnya dapat digunakan untuk menghitung rerata Time lag $\left(\mathbf{T}_{\text {lag }}\right)$ yang mencerminkan respons cepat akuifer karst terhadap curah hujan. Nilai ini identik dengan $T_{\text {lag }}$ pada hidrograf banjir.

6. Tlag pada phase functions dihitung menggunakan persamaan 16 yang telah dijelaskan diatas. Rumus untuk menghitung $\mathrm{T}_{\text {lag }}$ pada phase adalah, $\mathbf{T}_{\mathbf{l a g}}=\mathbf{n i l a i}$ phase pada frekuensi tertentu/ ( $2 \times$ phi $\times$ frekuensi pada saat phase tertentu).

7. Gambar 40 menunjukkan bahwa kelinieran terjadi pada frekuensi 0,001-0,094. Oleh karena itu, perhitungan $\mathrm{T}_{\text {lag }}$ dilakukan pada nilai pada seluruh phase yang ada pada range frekuensi 0,001-0,094 (Gambar 41). 


\begin{tabular}{|c|c|c|c|}
\hline $\begin{array}{c}\text { Frequency } \\
{[0, \mathrm{Pi}]}\end{array}$ & $\begin{array}{c}\text { Gua } \\
\text { Pindul } \\
\text { Phase }\end{array}$ & $\begin{array}{l}\text { Tlag Gua } \\
\text { Pindul }\end{array}$ & $\begin{array}{r}\text { Tlag Gu } \\
\text { Pindul }\end{array}$ \\
\hline 0,000 & 0,000 & & 4 \\
\hline 0,000 & 0,000 & & \\
\hline 0,001 & 0,000 & & \\
\hline 0,001 & 0,001 & 0,081 & \\
\hline 0,002 & 0,010 & 0,920 & \\
\hline 0,002 & 0,244 & 17,867 & \\
\hline 0,003 & 0,333 & 20,282 & \\
\hline 0,003 & 0,375 & 19,581 & \\
\hline 0,003 & 0,386 & 17,636 & \\
\hline 0,004 & 0,385 & 15,620 & \\
\hline 0,004 & 0,388 & 14,194 & \\
\hline 0,005 & 0,398 & 13,209 & \\
\hline 0,005 & 0,407 & 12,401 & \\
\hline 0,006 & 0,406 & 11,427 & \\
\hline 0,006 & 0,377 & 9,833 & \\
\hline 0,007 & 0,317 & 7,729 & \\
\hline 0,007 & 0,292 & 6.662 & \\
\hline
\end{tabular}

Gambar 41. Contoh perhitungan Tlag Gua Pindul dengan phase functions

8. Perhitungan Tlag Gua Pindul pada Gambar 41 tersebut diteruskan hingga frekuensi 0,094. Seluruh nilai tersebut kemudian dilakukan rerata, Hasil rerata nilai Tlag Gua Pindul adalah 4. Nilai tersebut perlu dikalikan 15 menit karena pencatatan debit dan hujan dilakukan setiap 15 menit sehingga Gua Pindul memiliki Tlag sebesar 60 menit (1 jam).

\subsection{Perhitungan Cross-Amplitude Functions}

1. Mencari hasil perhitungan cross-amplitude functions dari hasil perhitungan spectral analysis yang telah dijelaskan diatas. Perhitungan cross-amplitude functions berada di Tabel Cross-spectrum analysis (tabel ini biasanya terletak paling bawah dari hasil spectral analysis) (Gambar 42).

\begin{tabular}{|c|c|c|c|c|c|c|}
\hline $\begin{array}{c}\text { Frequency } \\
{[0, \mathrm{Pi}]}\end{array}$ & Period & Cospectrum & $\begin{array}{c}\text { Quadrature } \\
\text { spectrum }\end{array}$ & $\begin{array}{l}\text { Amplitude of the } \\
\text { cross-spectrum }\end{array}$ & $\begin{array}{l}\text { quared } \\
\text { herency }\end{array}$ & Phase \\
\hline 0,000 & & 100,446 & $-0,04$ & 100,446 & 3803,416 & 0,000 \\
\hline 0,000 & 14421,000 & 90,906 & $-0,04$ & 90,906 & 3596,742 & 0,000 \\
\hline 0,001 & 7210,500 & 65,966 & $-0,02$ & 65,966 & 2756,076 & 0,000 \\
\hline 0,001 & 4807,000 & 35,171 & 0,02 & 35,171 & 1060,517 & 0,001 \\
\hline 0,002 & 3605,250 & 10,284 & 0,10 & 10,284 & 100,924 & 0,010 \\
\hline 0,002 & 2884,200 & 0,770 & 0,19 & 0,794 & 0,611 & 0,244 \\
\hline 0,003 & 2403,500 & 0,762 & 0,26 & 0,807 & 0,652 & 0,333 \\
\hline 0,003 & 2060,143 & 0,818 & 0,32 & 0,879 & 0,923 & 0,375 \\
\hline 0,003 & 1802,625 & 0,916 & 0,37 & 0,989 & 1,123 & 0,386 \\
\hline 0,004 & 1602,333 & 1,009 & 0,40 & 1,088 & 0,920 & 0,385 \\
\hline 0,004 & 1442,100 & 1,047 & 0,42 & 1,131 & 0,695 & 0,388 \\
\hline 0,005 & 1311,000 & 0,996 & 0,41 & 1,081 & 0,630 & 0,398 \\
\hline 0,005 & 1201,750 & 0,836 & 0,36 & 0,911 & 0,708 & 0,407 \\
\hline 0,006 & 1109,308 & 0,625 & 0,26 & 0,680 & 0,977 & 0,406 \\
\hline ก กกศ & $1 \cap 2 n \cap 71$ & ก 158 & ก 18 & م0م-10 & 1276 & ก 277 \\
\hline
\end{tabular}

Gambar 42. Hasil perhitungan cross-amplitude functions yang ada di hasil perhitungan spectral analysis 
2. Salin hasil cross-amplitude functions dan frekuensi ke dalam sheet baru Ms.Excel (Gambar 43).

\begin{tabular}{|c|c|c|}
\hline $\begin{array}{c}\text { Frequency } \\
{[0, \mathrm{Pi}]}\end{array}$ & $\begin{array}{l}\text { Gua Pindul } \\
\text { Amplitude }\end{array}$ & $\begin{array}{c}\text { Kedungbuntung } \\
\text { Amplitude }\end{array}$ \\
\hline 0,000 & 100,446 & 55,339 \\
\hline 0,000 & 90,906 & 50,122 \\
\hline 0,001 & 65,966 & 36,479 \\
\hline 0,001 & 35,171 & 19,623 \\
\hline 0,002 & 10,284 & 5,981 \\
\hline 0,002 & 0,794 & 0,722 \\
\hline 0,003 & 0,807 & 0,655 \\
\hline 0,003 & 0,879 & 0,668 \\
\hline 0,003 & 0,989 & 0,714 \\
\hline 0,004 & 1,088 & 0,756 \\
\hline 0,004 & 1,131 & 0,762 \\
\hline 0,005 & 1,081 & 0,708 \\
\hline
\end{tabular}

Gambar 43. Cross-amplitude functions Gua Pindul dan Kedungbuntung

3. Membuat grafik cross-amplitude dengan cara blok ketiga kolom kemudian klik Insert $>>$ Scatter $>>$ Scatter with smooth line (langkah ini sama dengan langkah 6 perhitungan auto-correlation).

4. Atur rentang sumbu $\mathbf{x}$ (frekuensi) dan sumbu y (cross-amplitude functions (Sxy)) agar bentuk grafik yang naik-turun terlihat. Phase function merupakan perhitungan yang menunjukkan perilaku pemfilteran input signal (hujan) oleh sitem karst sebelum keluar sebagai output signal (debit). Perilaku pemfilteran tersebut ditunjukkan dengan adanya bentuk grafik yang naik-turun (Gambar 44 dan 45).

5. Nilai Sxy ketika mencapai 0 menunjukkan tidak adanya lagi pemfilteran oleh sistem karst. Oleh karena itu, Sxy bernilai 0 menunjukkan $\mathrm{T}_{\text {lag }}$ maksimum.

6. Gambar 44 menunjukkan bahwa Gua Pindul mencapai Sxy(f=0) pada frekuensi 0,14 sedangkan Kedungbuntung pada frekuensi 0,1. Untuk mengubah frekuensi menjadi durasi waktu, nilai frekuensi diubah menjadi pembagi (1/frekuensi). Durasi tersebut kemudian dikalikan 15 karena pencatatan debit dan hujan dilakukan setiap waktu 15 menit. Rumus pengubahan ini adalah $\mathrm{T}_{\mathrm{lag}}=1 /$ frekuensi ketika $\mathrm{Sxy}(\mathrm{f}=0)$.

7. Gua Pindul memiliki Tlag maksimal 1/0,14x15=1 jam 48 menit. Sementara itu, Kedungbuntung memiliki Tlag maksimal 1/0,1x15=2 jam 30 menit. 


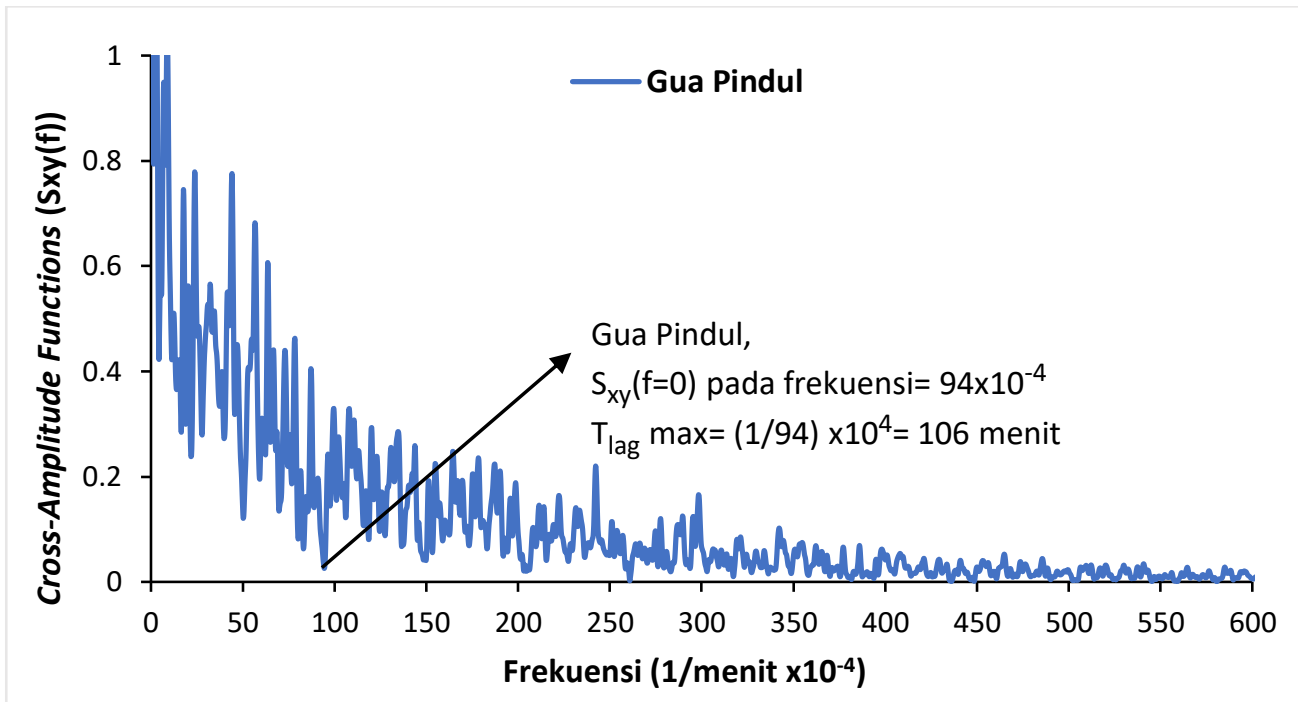

Gambar 44. Grafik cross-amplitude Gua Pindul

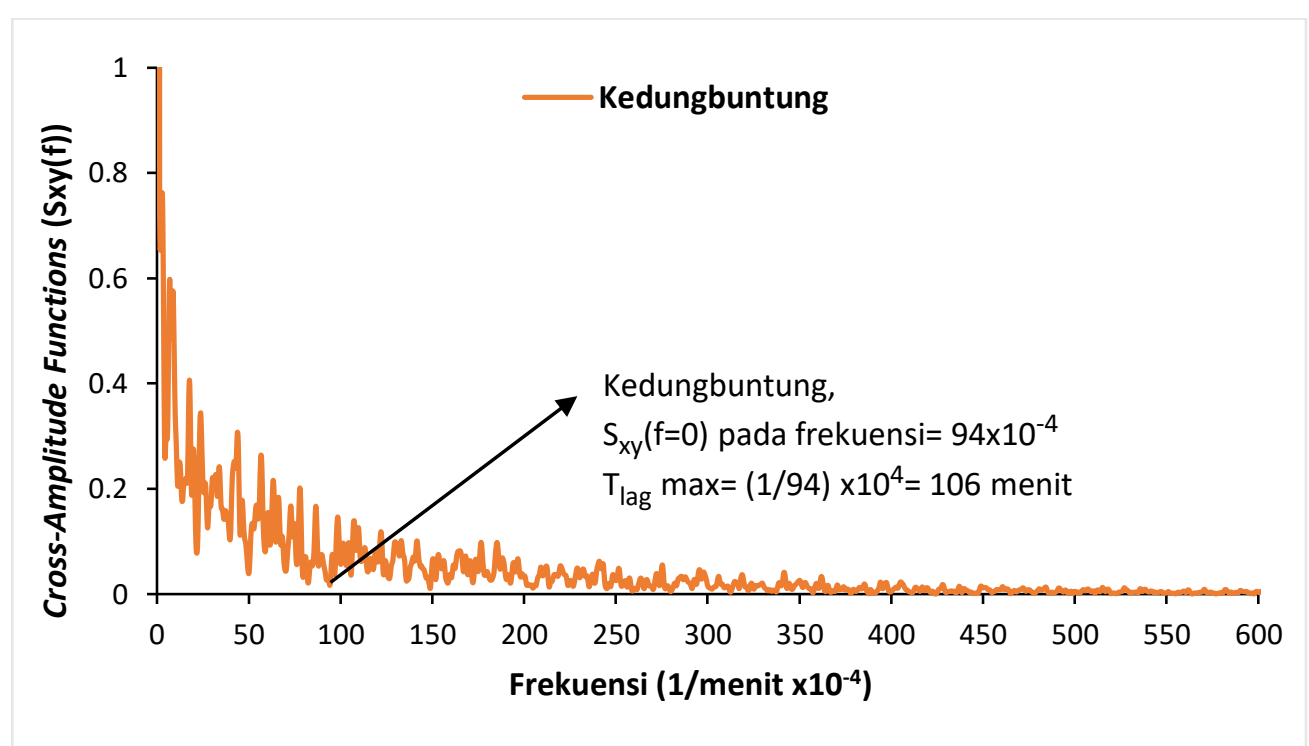

Gambar 45. Grafik cross-amplitude Kedungbuntung

\subsection{Perhitungan Spectral Density Functions}

1. Mencari hasil perhitungan spectral density dari hasil perhitungan spectral analysis yang telah dijelaskan diatas. Perhitungan spectral density berada di spectral analysis debit aliran (Gambar 46).

2. Salin hasil perhitungan spectral density dan frekuensi ke dalam sheet baru Ms.Excel (Gambar 47). 


\begin{tabular}{|r|r|r|r|r|r|}
\hline \multicolumn{2}{|l|}{ Results of the analysis of the Q2 series: } \\
\hline White noise tests (Q 2): \\
\hline
\end{tabular}

Gambar 46. Hasil perhitungan spectral density functions yang ada di hasil perhitungan spectral analysis

\begin{tabular}{|r|r|r|}
\hline $\begin{array}{c}\text { Frequency } \\
\text { [0,Pi] }\end{array}$ & $\begin{array}{c}\text { Gua Pindul } \\
\text { Spectral density }\end{array}$ & $\begin{array}{r}\text { Kedungbuntung } \\
\text { Spectral density }\end{array}$ \\
\hline 0,000 & 7,158 & 10,366 \\
\hline 0,000 & 6,558 & 9,554 \\
\hline 0,001 & 5,242 & 7,520 \\
\hline 0,001 & 4,632 & 5,550 \\
\hline 0,002 & 5,048 & 4,141 \\
\hline 0,002 & 5,806 & 3,394 \\
\hline 0,003 & 6,068 & 3,082 \\
\hline 0,003 & 5,478 & 2,711 \\
\hline 0,003 & 5,497 & 2,743 \\
\hline
\end{tabular}

Gambar 47. spectral density Gua Pindul dan Kedungbuntung

3. Membuat grafik spectral density dengan cara blok ketiga kolom kemudian klik Insert $>>$ Scatter $>>$ Scatter with smooth line (langkah ini sama dengan langkah 6 perhitungan auto-correlation).

4. Atur rentang sumbu $\mathbf{x}$ (frekuensi) dan sumbu $\mathbf{y}$ (spectral density) agar bentuk grafik yang naik-turun terlihat. Spectral density merupakan perhitungan yang menunjukkan durasi penyimpanan input signal (hujan) oleh sitem karst sebelum keluar sebagai output signal (debit). Perilaku penyimpanan tersebut ditunjukkan dengan adanya bentuk grafik yang naik-turun (Gambar 48).

5. Spectral density juga dapat menunjukkan rerata durasi pelepasan komponen baseflow dari seluruh kejadian banjir yang terjadi (durasi penyimpanan input signal 
oleh sistem karst). Konsep ini sama dengan perhitungan durasi dari grafik autocorrelation yang identik dengan resesi aliran diffuse.

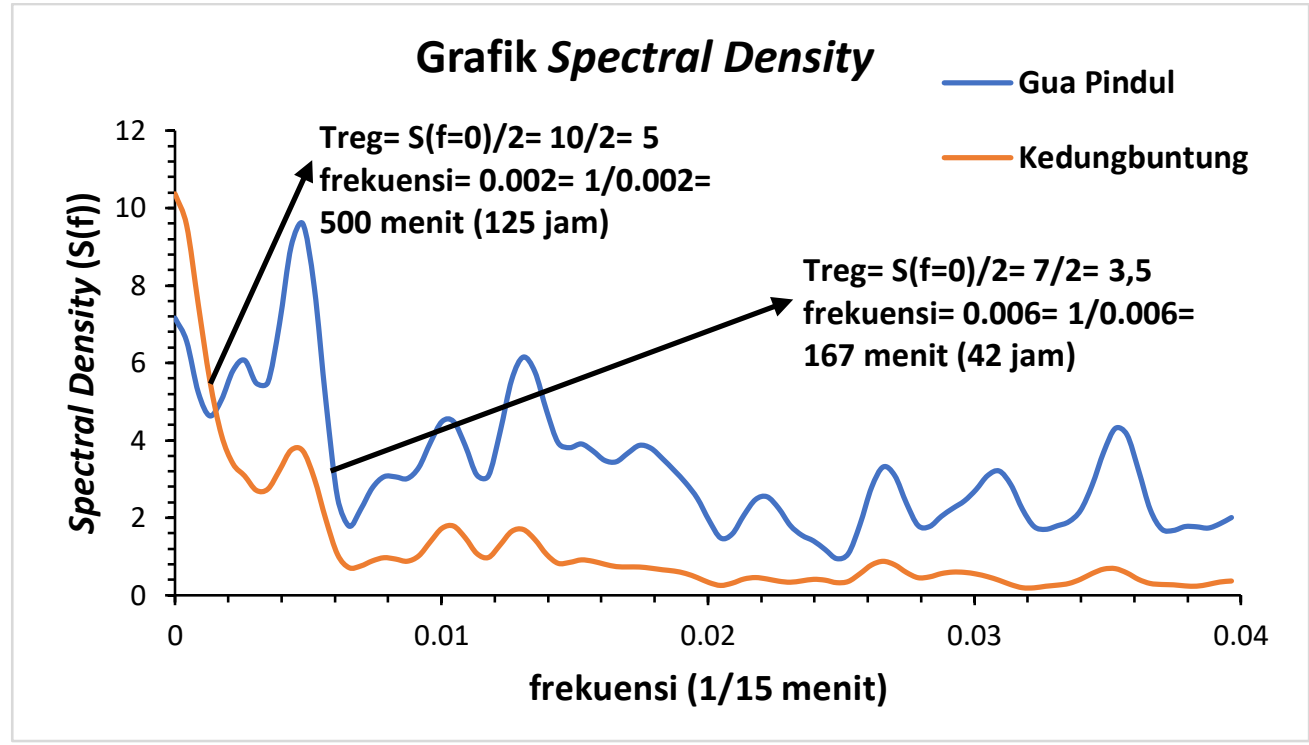

Gambar 48. Spectral density Gua Pindul dan Kedungbuntung

6. Perhitungan durasi aliran diffuse menggunakan konsep time regulatin $\left(\mathrm{T}_{\mathrm{reg}}\right)$ yang dijelaskan pada rumus 7 .

7. Gambar 48 menunjukkan bahwa Gua Pindul memiliki nilai spectral density saat frekuensi bernilai 0 sebesar 7. Treg Gua Pindul dapat dihitung dengan perhitungan, Treg $=7 / 2=3,5$. Nilai spectral density 3,5 terjadi pada frekuensi 0,006. Oleh karena itu, durasi aliran diffuse Gua Pindul adalah 1/0,006x15= 167 menit (42 jam).

8. Kedungbuntung memiliki nilai spectral density saat frekuensi bernilai 0 sebesar 10 . Dengan mengikuti langkah 7 diatas, Kedungbuntung memiliki durasi aliran diffuse sebesar $1 / 0,002=500$ menit $(125$ jam $)$.

\subsection{Perhitungan Gain Functions}

1. Gain functions dihitung menggunakan persamaan 18 yang telah dijelaskan diatas. Definisi persamaan tersebut adalah membagi hasil perhitungan cross-amplitude data debit-hujan dengan spectral density data hujan.

2. Data cross-amplitude dapat dicari dengan langkah 1 pada perhitungan crossamplitude. 
3. Data spectral density hujan dapat dicari dari hasil perhitungan spectral analysis yang telah dijelaskan diatas. Perhitungan spectral density hujan berada di spectral analysis hujan (Gambar 49).

\begin{tabular}{|r|r|r|r|r|}
\hline \multicolumn{2}{|l|}{ Results of the analysis of the $\mathbf{P}(\mathbf{m m})$ series: } \\
\hline White noise tests $(\mathrm{P}(\mathrm{mm}))$ : \\
\hline
\end{tabular}

Gambar 49. Spectral density hujan

4. Salin hasil perhitungan spectral density hujan, cross-amplitude dan frekuensi ke dalam sheet baru Ms.Excel. Kemudian, hitung nilai gain functions (Gambar 50).

\begin{tabular}{|c|c|c|c|}
\cline { 3 - 4 } $\begin{array}{c}\text { Frequency } \\
\text { [0,Pi] }\end{array}$ & $\begin{array}{c}\text { Gua Pindul } \\
\text { Amplitude }\end{array}$ & $\begin{array}{c}\text { Gua Pindul } \\
\text { Spectral density } \\
\text { Hujan }\end{array}$ & $\begin{array}{c}\text { Gua Pindul } \\
\text { Gain Functions }\end{array}$ \\
\hline 0,000 & 100,446 & 0,371 & 271,02 \\
\hline 0,000 & 90,906 & 0,350 & 259,49 \\
\hline 0,001 & 65,966 & 0,301 & 219,03 \\
\hline 0,001 & 35,171 & 0,252 & 139,68 \\
\hline 0,002 & 10,284 & 0,208 & 49,54 \\
\hline 0,002 & 0,794 & 0,177 & 4,47 \\
\hline 0,003 & 0,807 & 0,165 & 4,90 \\
\hline 0,003 & 0,879 & 0,153 & 5,75 \\
\hline 0,003 & 0,989 & 0,158 & 6,24 \\
\hline
\end{tabular}

Gambar 50. Perhitungan gain functions Gua Pindul

5. Membuat grafik gain functions dengan cara blok kolom frekuensi dan gain functions, kemudian klik Insert $>>$ Scatter $>>$ Scatter with smooth line (langkah ini sama dengan langkah 6 perhitungan auto-correlation).

6. Lakukan langkah 2-5 pada data lain untuk melakukan perbandingan (perhitungan ini menggunakan data Gua Pindul dan Kedungbuntung). 
7. Grafik gain functions menunjukkan durasi maksimum pelepasan aliran conduit pada nilai 0,4. Durasi minimum pelepasan aliran diffuse terjadi ketika nilai 1, dan durasi pelepasan aliran fissure terjadi pada rentang nilai gain functions (Gxy) 0,4-1 (Gambar 51 dan 52).

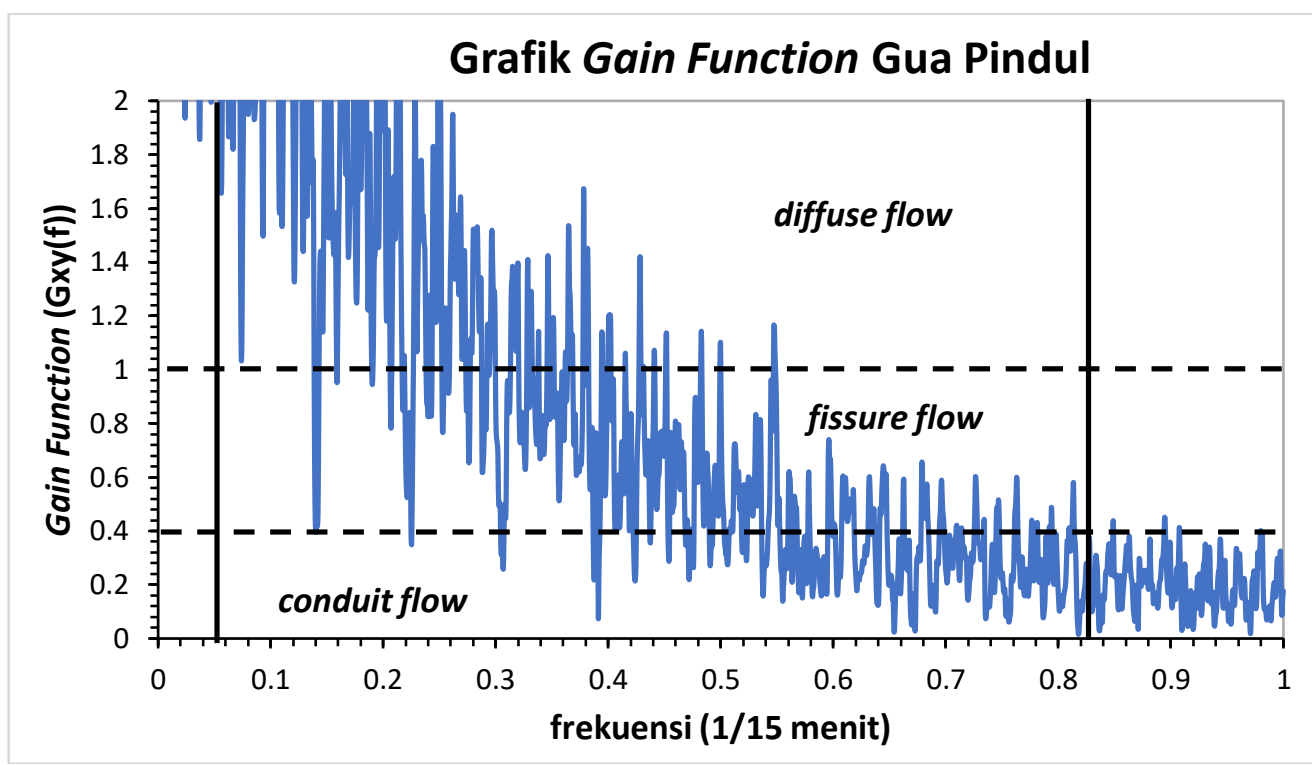

Gambar 50. Grafik gain functions Gua Pindul

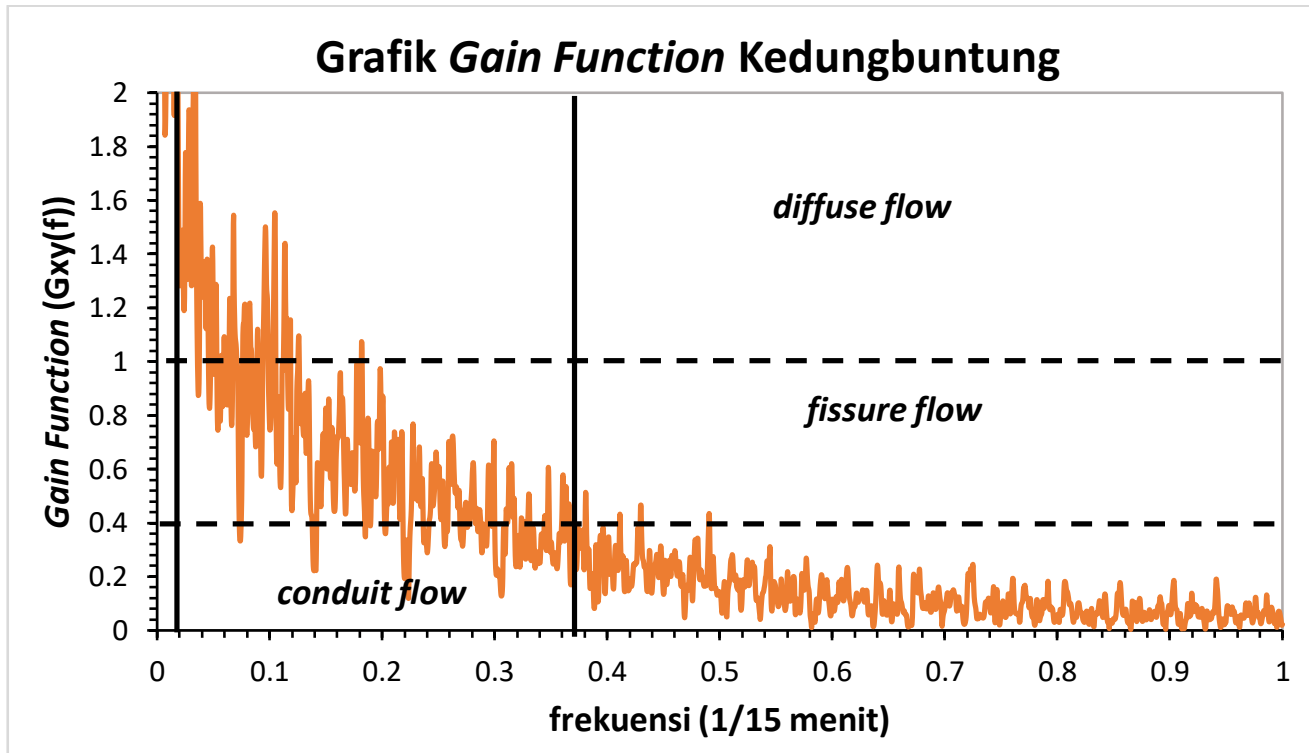

Gambar 51. Grafik gain functions Kedungbuntung

8. Gain functions Gua Pindul mulai mencapai nilai 0,4 pada frekuensi 0,83 sehingga memiliki durasi maksimum pelepasan aliran conduit $1 / 0,83 \times 15=18$ menit. Gua Pindul mulai mencapai nilai gain functions 1 pada frekuensi 0,05 sehingga 
memiliki durasi minimum pelepasan aliran diffuse 1/0,05x15=5 jam. Pelepasan aliran fissure Gua Pindul memiliki julat 18 menit-5 jam (Gambar 51).

9. Gain functions Kedungbuntung mulai mencapai nilai 0,4 pada frekuensi 0,37 sehingga memiliki durasi maksimum pelepasan aliran conduit 1/0,37x15=41 menit. Kedungbuntung mulai mencapai nilai gain functions 1 pada frekuensi 0,019 sehingga memiliki durasi minimum pelepasan aliran diffuse 1/0,019x15= 13 jam. Pelepasan aliran fissure Gua Pindul memiliki julat 41 menit-13 jam (Gambar 52). 


\section{Hasil}

Perhitungan time series analysis yang telah dilakukan pada BAB III dapat diklasifikan berdasarkan penelitian Zang, dkk (2013). Tabel 2 menunjukkan hasil klasifikasi dari perhitungan tulisan ini.

Tabel 2. Variasi nilai time series analysis Gua Pindul dan Kedungbuntung (Zang, dkk, 2013 dengan modifikasi)

\begin{tabular}{|c|c|c|c|c|c|}
\hline \multicolumn{2}{|c|}{$\begin{array}{c}\text { Respons Sistem } \\
\text { Akuifer Karst }\end{array}$} & \multirow{2}{*}{$\begin{array}{c}\text { Metode } \\
\begin{array}{c}\text { Cross- } \\
\text { Correlation }\end{array}\end{array}$} & \multirow{2}{*}{$\begin{array}{c}\text { Indikator } \\
\begin{array}{c}\text { waktu dari } \\
\text { puncak grafik }\end{array}\end{array}$} & \multirow{2}{*}{$\begin{array}{c}\begin{array}{c}\text { Kedungbuntung } \\
(\text { jam })\end{array} \\
1 \text { jam } 45 \text { menit }\end{array}$} & \multirow{2}{*}{$\begin{array}{c}\begin{array}{c}\text { Gua Pindul } \\
\text { (jam) }\end{array} \\
1 \text { jam } 45 \text { menit }\end{array}$} \\
\hline \multirow{4}{*}{$\begin{array}{l}\text { Aliran } \\
\text { Conduit }\end{array}$} & \multirow{3}{*}{$\begin{array}{l}\text { Waktu } \\
\text { Tunda } \\
\text { (Tlag) } \\
\text { Aliran } \\
\text { Conduit }\end{array}$} & & & & \\
\hline & & $\begin{array}{c}\text { Phase } \\
\text { Functions }\end{array}$ & $\begin{array}{c}\text { time } \operatorname{delay}(\mathrm{d})= \\
\theta \mathrm{xy}(\mathrm{f})) / 2 \pi \mathrm{f}\end{array}$ & 1 jam 11 menit & $1 \mathrm{jam}$ \\
\hline & & $\begin{array}{l}\text { Cross- } \\
\text { Amplitude }\end{array}$ & $\begin{array}{c}\text { nilai ketika } \\
\text { mendekati } \\
\text { enol }\end{array}$ & $<2,5$ jam & $\begin{array}{c}<1 \text { jam } 48 \\
\text { menit }\end{array}$ \\
\hline & $\begin{array}{l}\text { Durasi } \\
\text { Minimum } \\
\text { Aliran } \\
\text { Conduit } \\
\end{array}$ & $\begin{array}{c}\text { Gain } \\
\text { Functions }\end{array}$ & $\operatorname{gxy}(\mathrm{f})<0,4$ & $<41$ menit & $<18$ menit \\
\hline \multirow{3}{*}{$\begin{array}{l}\text { Aliran } \\
\text { Diffuse }\end{array}$} & \multirow{2}{*}{$\begin{array}{l}\text { Rerata } \\
\text { Durasi } \\
\text { Aliran } \\
\text { Diffuse }\end{array}$} & $\begin{array}{c}\text { Auto- } \\
\text { Correlation }\end{array}$ & $\begin{array}{c}\text { memory } \\
\text { effect }(C)= \\
2 /\left(\mathrm{n}^{\wedge} 0,5\right)\end{array}$ & $>125 \mathrm{jam}$ & $\begin{array}{l}45 \text { jam } 45 \\
\text { menit }\end{array}$ \\
\hline & & $\begin{array}{c}\text { Spectral } \\
\text { Density } \\
\text { Function }\end{array}$ & $\begin{array}{c}\text { regulation } \\
\text { time }(\text { Treg })= \\
\mathrm{S}(\mathrm{f}=0) / 2\end{array}$ & $125 \mathrm{jam}$ & $42 \mathrm{jam}$ \\
\hline & $\begin{array}{c}\text { Durasi } \\
\text { Maksimum } \\
\text { Aliran } \\
\text { Diffuse }\end{array}$ & $\begin{array}{c}\text { Gain } \\
\text { Functions }\end{array}$ & $\operatorname{gxy}(f)>1$ & $>13$ jam & $>5$ jam \\
\hline \multirow{3}{*}{$\begin{array}{l}\text { Aliran } \\
\text { Fissure }\end{array}$} & \multirow{2}{*}{$\begin{array}{l}\text { Rerata } \\
\text { Durasi } \\
\text { Aliran } \\
\text { Fissure }\end{array}$} & $\begin{array}{c}\text { Auto- } \\
\text { Correlation }\end{array}$ & $\begin{array}{l}\text { permulaan } \\
\text { penurunan } \\
\text { tajam grafik }\end{array}$ & $2,5 \mathrm{jam}$ & $2,5 \mathrm{jam}$ \\
\hline & & $\begin{array}{c}\text { Cross- } \\
\text { Correlation }\end{array}$ & $\begin{array}{c}\text { permulaan } \\
\text { penurunan } \\
\text { tajam grafik } \\
\end{array}$ & 4 jam & 4 jam \\
\hline & $\begin{array}{c}\text { Julat Durasi } \\
\text { Aliran } \\
\text { Fissure }\end{array}$ & $\begin{array}{c}\text { Gain } \\
\text { Functions }\end{array}$ & $0,4<\operatorname{gxy}(f)<1$ & $2,5-13 \mathrm{jam}$ & 18 menit- 5 \\
\hline
\end{tabular}




\section{DAFTAR PUSTAKA}

Ford, D. dan William, P. 2007. Karst Hydrogeology and Geomorphology. Netherlands: Springer.

Jemcov, I. dan Petric, M. 2009. Measured Precipitation Vs. Effective Infiltration and Their Influence on The Assessment of Karst Systems Based on Results of The Time Series Analysis. Journal of Hydrology v.379: p.304-314.

Kovacs, A. dan Sauter, M. 2007. Modelling Karst Hydrodynamics, In: Goldscheider, N. dan Drew, D., Methods in Karst Hyddrogeology, p.201-220. London: Taylor \& Francis Group.

Larocque, M., Mangin, A., Razack, M., Banton, O. 1998. Contribution of Correlation and Spectral Analyses to The Regional Study of a Large Karst Aquifer (Charente, France). Journal of Hydrology, v.205: p.217-231.

Mangin, A. 1984. Pour une meilleure conaissance des syste'mes hydrologiques a' partir des analyses corre'latoire et spectrale (For a Better Understanding of Hydrological Systems from Correlation and Spectral Analysis). Journal of Hydrology, v.67: p.25-43.

Padilla, A. dan Pulido-Bosch, A. 1995. Study of Hydrographs of Karstic Aquifers by means of Correlation and Cross-Spectral Analysis. Journal of Hydrology v.168: p.73-89.

Panagopoulos, G. dan Lambrakis, N. 2006. The Contribution of Time Series Analysis to The Study of The Hydrodynamic Characteristics of The Karst Systems: Application on Two Typical Karst Aquifers of Greece (Trifilia, Almyros Crete). Journal of Hydrology v.329 no.3-4: p.368-376.

Rahnemaei, M., Zare, M., Nematollahi, A.R., Sedghi, H. 2005. Application of Spectral Analysis of Daily Water Level and Spring Discharge Hydrographs Data for Comparing Physical Characteristics of Karstic Aquifers. Journal of Hydrology v.311: p.106-116.

Zhang, Z., Chen, Xi., Chen X., Shi, P. 2013. Quantifying Time Lag of Epikarst Spring Hydrograph Response to Rainfall Using Correlation and Spectral Analysis. Hydrogeology Journal v.21: p.1619-1631. 